\title{
A Literature Review on Stakeholder Participation in Coastal and Marine Fisheries
}

\author{
Heike Schwermer, Fanny Barz, and Yury Zablotski
}

\begin{abstract}
Stakeholder participation is a fundamental component of many states' and local agencies' fisheries legislations worldwide. The European Common Fisheries Policy (CFP), as one example, increasingly adopted a holistic approach to managing marine living resources. An important component of such an ecosystem-based management approach is the consideration of knowledge, values, needs and social interactions of stakeholders in decision-making processes. However, despite that stakeholder participation is a widely used term, a great variety of definitions exist, which often cause misunderstanding. Stakeholder participation is often used as part of conducting research on stakeholders but not in the context of their participation in resource management. Here, we present the results of a comprehensive literature review on the topic stakeholder participation in coastal and marine fisheries. We identified 286 scientific publications in Web of Science of which 50 were relevant for our research questions. Publications were analysed regarding (i) definition of stakeholder participation, (ii) analysis of participating stakeholders, (iii) applied participatory methods and (iv) intention for participation. Stakeholder types addressed in the publications included, e.g. fishery (fishers and direct representatives, $\mathrm{N}=48$ ), politics (policymakers and managers, $\mathrm{N}=31)$, science $(\mathrm{N}=25)$ and environmental nongovernmental organizations (eNGOs, $\mathrm{N}=24$ ). In total, 24 publications labelled their studies as stakeholder participation, while stakeholders were only used as a study object. We conclude that improving science and the practice of including stakeholders in the management of
\end{abstract}

H. Schwermer $(\bowtie)$

Institute for Marine Ecosystem and Fisheries Science, Center for Earth System Research and Sustainability, University of Hamburg Germany, Hamburg, Germany

e-mail: heike.schwermer@uni-hamburg.de

F. Barz · Y. Zablotski

Thünen-Institute of Baltic Sea Fisheries, Rostock, Germany coastal and marine fisheries requires definitions of who is considered a stakeholder and the form of participation applied.

\section{Keywords}

Case survey method $\cdot$ Stakeholder types $\cdot$ Participatory

methods · Multiple Correspondence Analysis

\subsection{Introduction}

Stakeholder participation is a fundamental component of many states' and local agencies' fisheries legislations worldwide (NOAA 2015). As an example, the Common Fisheries Policy of the European Union increasingly adopted a holistic approach to managing marine living resources (Commission of the European Communities 2013). An important component of such an ecosystem-based management (EBM) approach is the consideration of knowledge, values, needs and social interactions of resource users and other interest groups in decision-making processes (Long et al. 2015). Aanesen et al. (2014) established that in the case of fisheries management, this implies having access to local ecological knowledge of fishers to complement scientific data which is often very limited. Furthermore, involving stakeholders is expected to increase the legitimacy of the management by creating understanding and support among the stakeholders for management measures such as new regulations (Aanesen et al. 2014). Moreover, stakeholders represent varying preferences about a resource and, therefore, ideally enable processes to reach sustainable management on different levels, such as ecological and social. But the terms 'stakeholder' and 'participation' have become 'buzz words' in environmental management (Voinov and Bousquet 2010). Deviating definitions and explanations of both terms occur, and it is often unclear what is actually meant by these concepts. 
We here reviewed worldwide case studies to investigate how stakeholder participation is applied in research projects concerning coastal and marine fisheries. The literature review creates an overview of current meanings and methods applied in this research field. The aim of our study is to highlight and to critically discuss the application of the term stakeholder participation and the significance of these findings for future research projects in general and particular in the field of coastal and marine fisheries. In our study, we developed and applied nine questions to review and analyse relevant publications. First, we investigated the publications regarding the use of the term stakeholder. Here, we focused on term definition, approach of analysing stakeholders as well as on the stakeholder types involved in the case study. Subsequently, we reviewed the publications in relation to the term participation, again first focusing on term definition, methods used related to the participation of stakeholders, description and intention for participation. Finally, we analysed all publications to evaluate whether the publications used participation as a tool for researching stakeholders (research tool) or for conducting true stakeholder participation (participation tool).

Our study revealed that only few publications in the research field of coastal and marine fisheries clearly defined the terms stakeholder and participation. Furthermore, the majority of publications labelled their studies as stakeholder participation, while stakeholders were only used as a study object. We conclude that improving the science and the practice of including stakeholders in the management of coastal and marine fisheries requires definitions of who is considered a stakeholder and the form of participation applied.

\subsection{Material and Methods}

We conducted a systematic literature review using the case survey method (Newig and Fritsch 2009), i.e. one article represented one analysis unit. Here, qualitative studies were transformed into semi-quantitative data, applying a coding scheme and expert judgements by multiple coders. The case survey method allowed us to synthesize case-based knowledge using at least two coders. We translated our research steps (RS) into a research protocol, adapted after Brandt et al. (2013), making RS repeatable and transparent. Our study included five working steps (WS): data gathering (WS 1), data screening (WS 2), data cleaning (WS 3), paper reviews (WS 4) and a statistical analysis of the collected data (WS 5) (Table 2.1).

In WS 1 we derived relevant publications from the Web of Science (WoS; www.isiknowledge.com), an extensive and multidisciplinary database covering a large number of scientific journals, books and proceedings in the field of natural science and technique, arts, humanities and social sciences (ETH Zürich 2018). We extracted articles published within the period from 2000 to 2018, considering the establishment of participation in (environmental) decision-making processes as a democratic right by the United Nations Economic Commission for Europe's 1998 Arhus Convention and an increased use (Reed 2008). To ensure an establishment in research publications, we started the review two years later. Publications were collected by using the basic search routine in the WoS (date of search: 16 May 2018) applying the following keyword strings: (i) stakeholder - participation - fishery, (ii) stakeholder - involvement - fishery and

Table 2.1 The five working steps (WS) of our literature review on stakeholder participation in the field of coastal and marine fisheries consisted of data gathering, data screening, data cleaning, paper review and statistical analysis. The review procedure and the results are presented for each WS

\begin{tabular}{l|l|l}
\hline $\begin{array}{l}\text { Working step } \\
\text { (WS) }\end{array}$ & Review procedure & Result \\
\hline $\begin{array}{l}\text { 1. Data } \\
\text { gathering }\end{array}$ & $\begin{array}{l}\text { Definition of Web of Science query (keywords: } \\
\text { stakeholder, participation/engagement/involvement, } \\
\text { fishery; 16 May 2018) }\end{array}$ & $\begin{array}{l}\text { Bibliographical information of 286 potentially relevant } \\
\text { publications }\end{array}$ \\
\hline $\begin{array}{l}\text { 2. Data } \\
\text { screening }\end{array}$ & $\begin{array}{l}\text { Screening of publications guided by the question: } \\
\text { Are all three keywords listed within the title, abstract or } \\
\text { keywords of the publication? }\end{array}$ & A total of 81 publications were identified \\
\hline $\begin{array}{l}\text { 3. Data } \\
\text { cleaning }\end{array}$ & $\begin{array}{l}\text { Cleaning of publications guided by the questions: } \\
\text { i) Does the publication focus on coastal and marine } \\
\text { fisheries? } \\
\text { ii) Are the publications case studies? }\end{array}$ & A total of 50 relevant publications were identified \\
\hline $\begin{array}{l}\text { 4. Paper } \\
\text { review }\end{array}$ & $\begin{array}{l}\text { Content analysis of relevant publications using a set of } \\
\text { nine research questions concerning the term stakeholder } \\
\text { participation }\end{array}$ & $\begin{array}{l}\text { Different definitions and methods regarding the topic } \\
\text { stakeholder participation in the field of coastal and marine } \\
\text { fisheries were identified }\end{array}$ \\
\hline $\begin{array}{l}\text { 5. Statistical } \\
\text { analysis }\end{array}$ & $\begin{array}{l}\text { Analysis of data using multiple correspondence analysis in } \\
\text { R }\end{array}$ & Results are presented in this review publication \\
\hline
\end{tabular}


(iii) stakeholder - engagement - fishery. We additionally used the string 'fisheries' instead of 'fishery'.

In WS 2 we screened all publications derived in WS 1; we only further considered the publications that included all three keywords stakeholder, participation/involvement/ engagement and fishery in (i) the title, (ii) the abstract or (iii) the keywords. We also included publications that either used the noun, the verb, i.e. to fish, to participate/ involve/engage, or the adverb of the keyword, like 'fishing community'.

For the data cleaning (WS 3), we used an inductive approach to identify key issues of selected publications based on two characteristics:

1. Focus of the publication - fisheries, freshwater or estuarine ecosystems, recreational fisheries or marine protected areas; management (e.g. fishery, coastal management, EBM) or policy (e.g. Common Fisheries Policy (CFP), Marine Strategy Framework Directives (MSFD))

2. Study type of publication - a participation case study, a meta-analysis of participation studies or participation framework description

We here described policy as a set of rules or an established framework; management was defined by general environmental management approaches (e.g. ecosystem-based management (EBM), coastal management) or explicit management measures.

In WS 3 we excluded publications with focus on freshwater or estuarine ecosystems, recreational fisheries and marine protected areas. In addition, we discarded publications with focus on coastal management and EBM as well as publications looking at political frameworks (CFP, MSFD). All remaining publications focused on coastal and marine fisheries.

We further only analysed publications that presented a case study; in WS 3 we discarded studies that represented a meta-analysis or theoretical participation framework description. We here defined a case study as "[...], analyses of persons, events, decisions, periods, projects, policies, institutions, or other systems that are studied holistically by one or more methods. The case that is the subject of the inquiry will be an instance of a class of phenomena that provides an analytical frame — an object - within which the study is conducted and which the case illuminates and explicates" (Thomas 2011). For an evaluation of the regional distribution, we also extracted the continent where the case study has been conducted.

In WS 4 we analysed the content of the finally selected papers applying a mixed-method approach. We evaluated the publications based on 9s questions, investigating the terms stakeholder (questions 1-4) and participation (questions
5-8) first separately and subsequently in combination (question 9). The list of questions is shown in Table 2.2. We applied a quantitative approach to investigate naming and definition of both terms (questions 1-8, Table 2.2). Furthermore, we applied an inductive approach to generate categories for analysing derived data to elicit which type of stakeholders, participation tools and intention categories for participation were part of the research projects (questions 2, 6 and 8, Table 2.2) (Mayring 1988). Eight stakeholder types were distinguished in our analysis, i.e. science, politics, environmental non-governmental organizations (eNGOs), fisheries, fishery-related industry, recreational fisheries, public and others. Although we excluded publications that focus on recreational fisheries, this stakeholder type was part of the case studies focusing on coastal and marine fisheries and, therefore, was included as one stakeholder type within our analysis. The category 'others' included stakeholders that did not fit into any of the other categories but have been explicitly mentioned separately from them. We similarly analysed questions 6 and 8. Here, we distinguished between 11 participatory methods, i.e. workshop, interview, meeting, discussion, survey, questionnaire, modelling, coordination, mapping, presentation and conversation, and 10 intention categories, i.e. analysis, assessment, definition, description, development, establishment, evaluation, feedback, identification and improvement. Related to the description in the publications, we distinguished between active and passive participatory methods: active ones describing methods that directly involved stakeholders in decision-making processes; passive participatory methods had been described to support the participatory process but not to involve the stakeholders

Table 2.2 Nine questions used to review the identified case studies in coastal and marine fisheries management. The terms stakeholder (questions 1-4) and participation (questions 5-8) were investigated separately and in combination, i.e. stakeholder participation (question 9)

\begin{tabular}{l|l}
\hline Term & Question \\
\hline \multirow{2}{*}{ Stakeholder } & $\begin{array}{l}\text { 1. How is the term stakeholder defined? } \\
\text { 2. Which types of stakeholder are part of the } \\
\text { research project? }\end{array}$ \\
\cline { 2 - 2 } & $\begin{array}{l}\text { 3. Was a systematic approach used to analyse } \\
\text { stakeholders? }\end{array}$ \\
\cline { 2 - 2 } & $\begin{array}{l}\text { 4. Which stakeholder analysis approach was } \\
\text { used? }\end{array}$ \\
\hline Participation & $\begin{array}{l}\text { 5. Was the term participation/engagement/ } \\
\text { involvement defined? }\end{array}$ \\
\cline { 2 - 2 } & $\begin{array}{l}\text { 6. Which participation/engagement/involvement } \\
\text { methods were mentioned? }\end{array}$ \\
\cline { 2 - 2 } & $\begin{array}{l}\text { 7. How was the participation/engagement/ } \\
\text { involvement method described? }\end{array}$ \\
\cline { 2 - 2 } & $\begin{array}{l}\text { 8. What was the aim of using participation within } \\
\text { this project? }\end{array}$ \\
\hline \multirow{2}{*}{$\begin{array}{l}\text { Stakeholder } \\
\text { participation }\end{array}$} & $\begin{array}{l}\text { involvement tool used for analysing stakeholders } \\
\text { (research tool) or for involving stakeholders } \\
\text { (participation tool)? }\end{array}$ \\
\hline
\end{tabular}


Fig. 2.1 Number of research publications published from 2000 to 2018 dealing with case studies in coastal and marine fisheries as found by Web of Science (keywords: stakeholder, participation/ engagement/involvement, fishery) as of May 2018. Black line represents the linear regression with $95 \%$ confidence intervals; the grey area indicates the confidence band $\left(\mathrm{R}^{2}=0.6045\right.$, $\mathrm{p}=0.000645)$

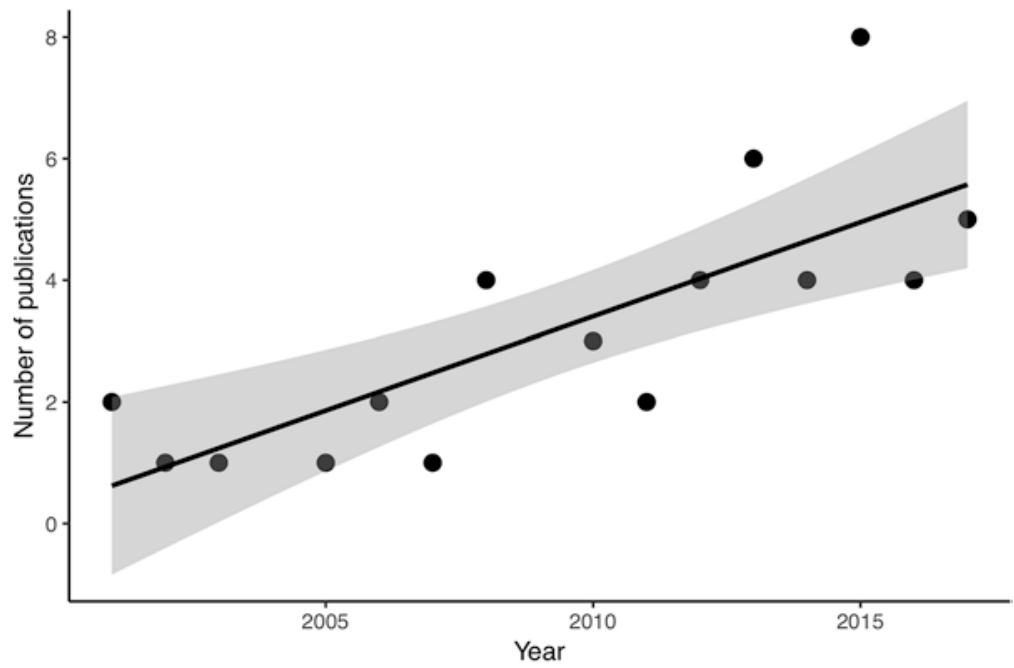

in research or management (decision-making processes). Participatory methods and intention categories were extracted according to the mention in the publications. Related to the participatory methods, we also determined whether preparatory work was done using an inductive approach.

Eventually, we investigated whether (i) the case studies conducted participation to gather knowledge from stakeholders but without engaging these stakeholders in a decision-making process (research tool) or (ii) stakeholders had a direct influence on data interpretation and decisionmaking processes (participation tool).

In the final working step (WS 5 - statistical analysis), we used Multiple Correspondence Analysis (MCA) to explore the relationships between stakeholder types. MCA is able to uncover correlations (i.e. similarities, grouping) in otherwise inconvenient survey data (Higgs 1991) and was designed to apply on multiple binary (or nominal) variables (e.g. our categories stakeholder 'science' absent $=0$, present $=1$; stakeholder 'public': absent $=0$, present $=1$ ), all of which had the same status (Abdi and Valentin 2007). MCA explores the patterns in data by measuring the geometric proximity between stakeholder types (e.g. science and public) using weighted least squares (Abdi and Valentin 2007) and graphically represents the proximity of the categories on a simple plane, i.e. correspondence map. Thus, MCA allows finding similarities between categories based on the chi-square distance between them and using the percentage of the explained variance to the new (reduced) dimensions. More details related to the method of MCA can be found in the original work Greenacre (1984). We used MCA to answer the question: Which stakeholder types often appear together in the reviewed publications?

\subsection{Results}

We identified in total 286 scientific publications, which we further analysed according to our review protocol (see Sect. 2).

Of 286 publications, in total 81 contained all keywords of which 56 publications had their emphasis on coastal and marine fisheries. 50 publications out of 56 were categorized as case studies and were further analysed in our study (detailed description in Table 2.A1 of the Supplementary Material).

The number of publications that focused on stakeholder participation significantly increased within the last 18 years (Fig. 2.1). In 2015, a maximum value of eight was reached. The majority of the case studies was conducted in Europe $(\mathrm{N}=18)$, North America $(\mathrm{N}=11)$ and Australia $(\mathrm{N}=9)$.

\subsubsection{Paper Review: Stakeholders}

\subsubsection{Term Definition}

We identified four publications defining the term stakeholder (Brzezinski et al. 2010; Haapasaari et al. 2013; Tiller et al. 2015; Kinds et al. 2016) (Fig. 2.2a). Even though they defined the term more indirectly and in general, Brzezinski et al. (2010) stated stakeholders as members of a particular group that hold a personal stake. They referred to Olson (1965) to suggest that the increase of the personal stake of these members will lead to an increase of their participation in regulatory processes. Haapasaari et al. (2013) described stakeholders as a group of people having a stake and contributing towards a knowledge base for fisheries management. On the other hand, Kinds et al. (2016) focused on stakeholders as all people and organizations (here producer organizations), which are actively involved in the fishing sector. Tiller 

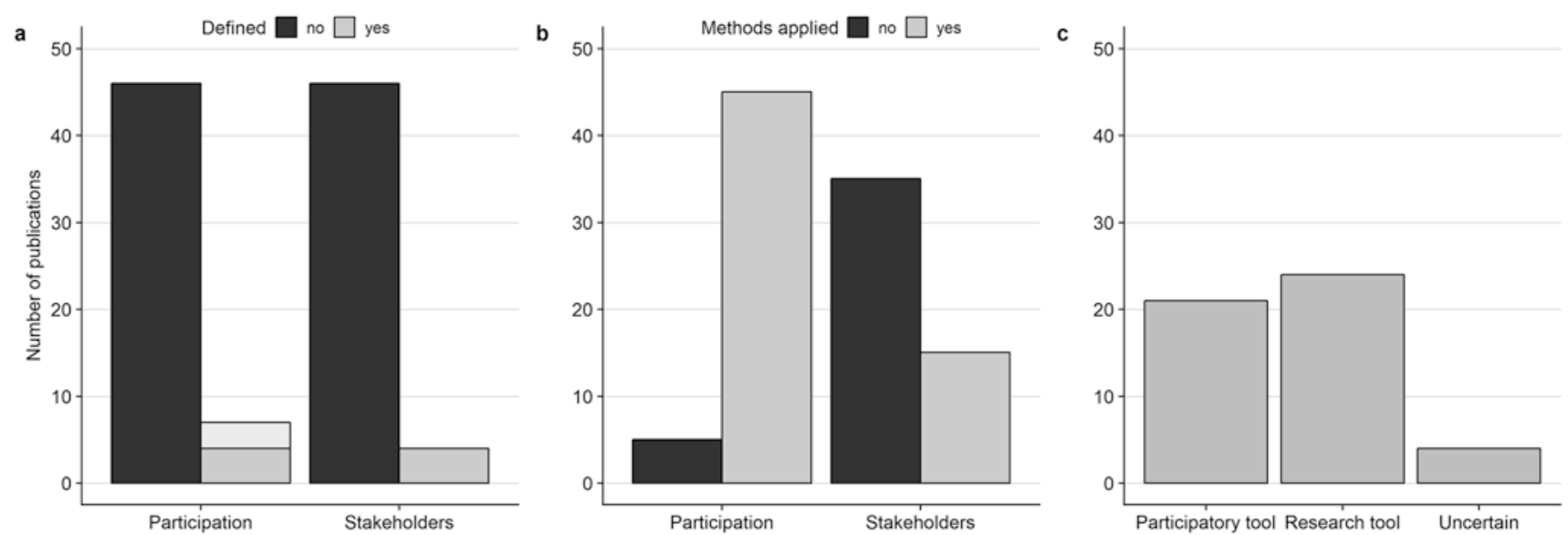

Fig. 2.2 Review of 50 research publications presenting case studies in coastal and marine fisheries (as of May 2018). (a) Term definition of participation and stakeholder; we distinguished between participation (grey) and participation-related terms (light grey), e.g. participatory management, participatory research and participatory action research; (b) method application for participation (e.g. interview, workshops and questionnaire) and stakeholders (e.g. snowball sampling); (c) the use of stakeholder participation, either as a participation or research tool et al. (2015) took a deliberate look into the literature, referring to Freeman (2010). Freeman (2010) defined stakeholders as any group or individual who can affect, or is affected by, the achievement of the organization's objectives (Freeman 2010). Tiller et al. (2015) continued to criticize this definition as too broad; it allows the inclusion of nearly everyone as a stakeholder.

\subsubsection{Stakeholder Analysis}

Durham et al. (2014) stated that the selection of stakeholders strongly determines the outcome of the participation process. They, therefore, recommended to systematically select stakeholders based on the objective and impact of research. We, therefore, analysed the publications, looking for the description or reference of stakeholder analysis processes.

In our review corpus, 15 out of 50 publications applied methods to get an understanding of who their stakeholders are (Fig. 2.2b). We evaluated publications as using stakeholder analysis approaches if the case studies did not decide on stakeholder groups or stakeholder individuals (referring to Durham et al. 2014) but researched for them systematically. Three out of 15 publications defined stakeholder groups, three determined stakeholder groups as well as individual stakeholders and the remaining nine out of 15 case studies selected individual stakeholders out of a priori stakeholder groups.

Gray et al. (2012), Kinds et al. (2016), as well as Sampedro et al. (2017) evaluated stakeholder groups that were involved in past fisheries research and management; thereby, they have chosen the group of stakeholders they wanted to involve in their current research projects. Pristupa et al. (2016) applied three different approaches; on the one hand, they did not want to overlook a major stakeholder, and on the other hand, they aimed to identify the most knowledgeable indi- vidual within the appropriate stakeholder group: first they extracted information from reports and open-access information such as Marine Stewardship Council reports, interviews on specialized websites and scientific reports. Second, they identified stakeholders during a thematic conference, which was also used to establish contacts. Third, recommendations by fisheries experts were accumulated using the snowball approach (Pristupa et al. 2016). Different to the previous case studies, Miller et al. (2010) used two approaches to select relevant stakeholders. First, stakeholders were selected due to history, perspectives and relationships among those with a stake in a specific fishery (Miller et al. 2010). Second, relevant stakeholders should be knowledgeable and influential in their community as well as open minded for different views (Miller et al. 2010). Further, Mahon et al. (2003) analysed stakeholders based on public records before organizing discussion meetings where individual stakeholders were singled out.

Additionally, nine publications described methods that were applied to identify individual stakeholders, either within presumed stakeholder groups or randomly. Butler et al. (2015), Bitunjac et al. (2016) and Stratoudakis et al. (2015) based their choice of individual stakeholders on their long-time experience and their knowledge of the topic studied. Bitunjac et al. (2016) selected stakeholders of which the authors assumed to have a leading influence within their group and were, therefore, seen as representatives of their stakeholder group. Catedrilla et al. (2012), Kerr et al. (2006) and Murphy et al. (2015) had chosen fishers as individual stakeholders by sampling them from a registration list in their field of interest. Lorance et al. (2011) and Thiault et al. (2017) selected the stakeholders at random. Lorance et al. (2011) advertised workshops widely and, therefore, could not directly influence attendance; Thiault et al. (2017) did 
sampling among all households in their area of interest without focusing on a specific stakeholder group. Kittinger (2013) first conducted a snowball sampling followed by a 'purposive sampling approach' - a deliberately selective approach choosing knowledgeable individuals.

\subsubsection{Stakeholder Types}

Overall the stakeholder type 'fishery' had the highest frequency of appearance within all publications, followed by 'politics', 'science' and 'eNGO' (Table 2.3). In five publications, 'fishery' was considered as the only stakeholder (Clarke et al. 2002; Catedrilla et al. 2012; Eveson et al. 2015; Tiller et al. 2015; Thiault et al. 2017). Except for Catedrilla et al. (2012), these publications aimed at getting information about the spatial distribution of fishing grounds. Two case studies (Fletcher 2005; Dowling et al. 2008) did not name 'fishery' as a stakeholder but noted that fishers were involved in the conducted case study.

'Politics', 'science' and 'eNGO' were targeted in about half of the studies. Nonetheless, 12 case studies did not consider any of these three stakeholders at all (e.g. Mitchell and Baba 2006; Appledorn et al. 2008; Cox and Kronlund 2008). The stakeholder type 'others' mostly represented a business or the like (e.g. Carr and Heyman 2012; Butler et al. 2015). 'Public' stakeholders were mainly seen as community members (Kittinger 2013; Eriksson et al. 2016) or consumers (Mahon et al. 2003), who, therefore, did not have a primary economic or political interest in fisheries.

'Related industry' was described as processing and selling industry that was directly associated with fisheries and so depended on this stakeholder type (e.g. Cox and Kronlund 2008). 'Related industry' was considered 16 times in the

Table 2.3 Identified stakeholder types presented by case studies in coastal and marine fisheries (as of May 2018) and ranked by the frequency of their appearance $(\mathrm{N})$. Description of stakeholder types corresponds to the one mentioned in the publication under review

\begin{tabular}{|c|c|c|}
\hline $\begin{array}{l}\text { Stakeholder } \\
\text { type }\end{array}$ & Description of stakeholders & $\mathrm{N}$ \\
\hline Fishery & Fishers and their direct representatives & 48 \\
\hline Politics & $\begin{array}{l}\text { Government officials, local and village } \\
\text { officers }\end{array}$ & 31 \\
\hline Science & Academic scientists & 25 \\
\hline eNGO & $\begin{array}{l}\text { Environmental non-governmental } \\
\text { organizations }\end{array}$ & 24 \\
\hline Others & $\begin{array}{l}\text { E.g. local businesses, leaders of the tourism } \\
\text { sector, leaders of other community-based } \\
\text { associations }\end{array}$ & 17 \\
\hline $\begin{array}{l}\text { Related } \\
\text { industry }\end{array}$ & Processing and selling businesses & 16 \\
\hline Public & $\begin{array}{l}\text { Community members, representatives from } \\
\text { public organizations, consumers }\end{array}$ & 7 \\
\hline $\begin{array}{l}\text { Recreational } \\
\text { fishery }\end{array}$ & Representatives of recreational fishery & 5 \\
\hline
\end{tabular}

reviewed case studies and differed widely in their topics in which context these stakeholder groups emerged, e.g. bycatch (Bojorquez-Tapia et al. 2016), stock assessment (Smith et al. 2001) or compliance (Garza-Gil et al. 2015). 'Recreational fishery' was represented in five publications, two in Australia (Fletcher 2005, Mitchell and Baba 2006) and three in North America (e.g. Miller et al. 2010; Gray et al. 2012; Murphy et al. 2015), all of them focused on management processes.

\subsubsection{Relationships Between Stakeholder Types}

We applied a multiple correspondence analysis to evaluate the occurrence of certain stakeholder clusters. 48 publications included 'fishery' as a stakeholder, but this stakeholder type did not group with other stakeholders and, therefore, lessened the meaningfulness of other stakeholders. For this reason, we decided to exclude 'fishery' from the MCA, which resulted in a higher percentage of the variance explained by the dimensions. As a result, very similar variable clusters of categories appeared and were, therefore, easier to interpret. 'Others' were also excluded from the MCA; by definition this stakeholder type showed a great variety, and, therefore, interpretation of the data would be difficult.

Ideally, dimensions should be used to interpret the data whose eigenvalues exceed the mean of all eigenvalues (0.17). For this reason, we included three dimensions into our analysis, which together accounted for over $70 \%$ of the variance. Here, it is important that the dimensions obtained are hierarchical. Dimension 1 formed the strongest dimension (Dim1, Fig. 2.3, Table 2.A2 of the Supplementary Material), i.e. singled out 'science', 'eNGO' and 'politics', and explained $31.6 \%$ of the variance. Further, these three stakeholder types had the highest number of mentions after 'fishery'. Dimension 2 (Dim 2, Fig. 2.A2a of the Supplementary Material) focused on 'recreational fishery' and 'related industry', accounting for $21.8 \%$ of the variance. Although 'recreational fishery' was only considered in five case studies, this stakeholder type showed a strong contribution towards dimension 2. Also, explanatory power was increased by sharing contribution with 'related industry'. Less variance $(17.7 \%)$ was explained by dimension 3, which was dominated by 'public' (Dim 3, Fig. 2.A2b, Table 2.A1 of the Supplementary Material).

Subsequently, MCA was applied separately to case studies from North America $(\mathrm{N}=10)$ and Europe $(\mathrm{N}=18)$ (Fig. 2.A3a-c of the Supplementary Material). The results of the MCA that was performed on North America case studies showed a similar picture as in Fig. 2.3, although these case studies did not dominate the review corpus. Even though 'science', 'eNGO' and 'politics' showed a strong contribution in different dimensions, these stakeholder types could 


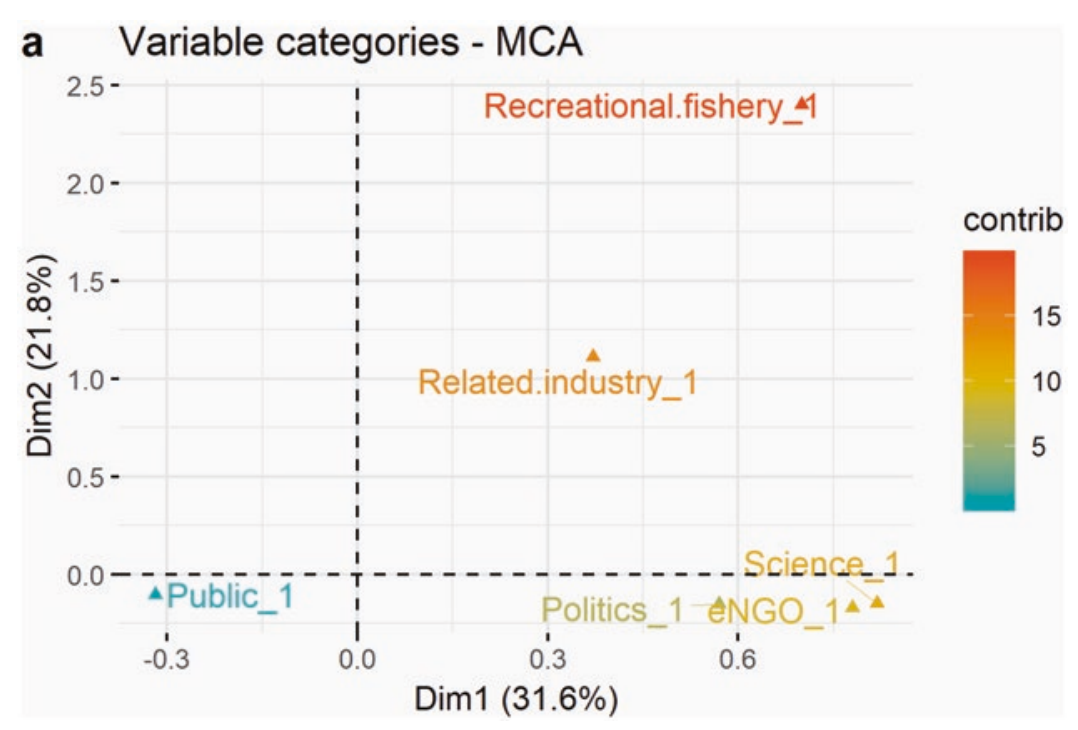

Fig. 2.3 Panel a of the visualization of correlation between dimension 1 (Dim1) and dimension 2 (Dim2), showing the variance of stakeholder types in 50 research publications of case studies in coastal and marine fisheries (as of May 2018) using multiple correspondence analysis (MCA). Figure shows which types of stakeholders are mostly corre-

still be found as a group. In dimension 2 'related industry' and 'recreational fishery' were displayed in the negative area; the other stakeholder types moved from the negative area of dimension 2 into the positive area. 'Related industry' and 'recreational fishery' were also grouped together with a high contribution as seen in Fig. 2.A3a (Supplementary Material); 'public' was found apart.

We showed clearly that in European case studies, 'related industry' and 'public' as well as 'science' and 'eNGO' grouped together. 'Politics' was rather set apart and did not contribute much to dimension 1. 'Politics' solely dominated dimension 3; 'recreational fishery' did not appear in the case studies conducted in Europe.

\subsubsection{Paper Review: Participation}

\subsubsection{Term Definition}

In total, four publications defined the term participation (Brzezinski et al. 2010; Tiller et al. 2015; Pristupa et al. 2016; Sampedro et al. 2017); three publications described participation-related terms (Kittinger 2013; Hara et al. 2014; Trimble and Lazaro 2014) (Fig. 2.2a). After Sampedro et al. (2017), participation could take many different forms, e.g. from planning (Neis et al. 1999; Johannes and Neis 2007; Johnson and van Densen 2007) to co-management experiences (Berkes 2003; Wilson et al. 2003). Participation was described as a role that benefits the participating stakeholders (Brzezinski et al. 2010) and a strategy of involving the lated, i.e. regarding stakeholder participation in coastal and marine fisheries, 'eNGO', 'politics' and 'science' are often addressed together. Panels $\mathrm{b}$ and $\mathrm{c}$ of the MCA results for correlation of dimension 2 (Dim2) and 3 (Dim3) as well as dimension 1 (Dim1) and 3 (Dim3) are presented in Fig. A2 of the Supplementary Material

stakeholders in decision-making processes (Tiller et al. 2015). Further, dependent on the strategy of involvement, stakeholders could get further responsibilities in the results of the conducted participatory process (Tiller et al. 2015). Moreover, participation referred to the type and level of stakeholder or beneficiary involvement (Hickey and Kothari 2009; Pristupa et al. 2016). Pristupa et al. (2016) explained that countries had developed a whole range of formal mechanisms stipulating citizens and stakeholder participation, e.g. consultations, referendums and elections; the participation of the private sector was still challenging.

Within three case-study publications, participatoryrelated terms had been described, e.g. participatory management (PM, Hara et al. 2014), participatory research (Trimble and Lazaro 2014) and participatory action research (PAR, Kittinger 2013). PM or co-management was defined as an institutional and organizational arrangement for effective management between government and user groups (Hara et al. 2014). The function of PM was described as the sharing of power and the responsibility for the management decisionmaking, the encouragement of partnerships and provision of user incentives for sustainable use of resources (Wilson et al. 2003; Hara et al. 2014). Participatory research was defined as one way to create power sharing between researchers and communities for, e.g. developing resource management strategies (Arnold and Fernandez-Gimenez 2007; Trimble and Lazaro 2014). Related to the degree of participation or the relationships between researchers and the community, different modes of participatory research occurred (Trimble 

appearance of active (workshop, interview, meeting, discussion, questionnaire, survey, modelling, conversation, mapping) and passive participation tools (coordination, presentation), related to stakeholder participation described in coastal and marine fisheries research publications (as of May 2018)
Fig. 2.4 Frequency of the

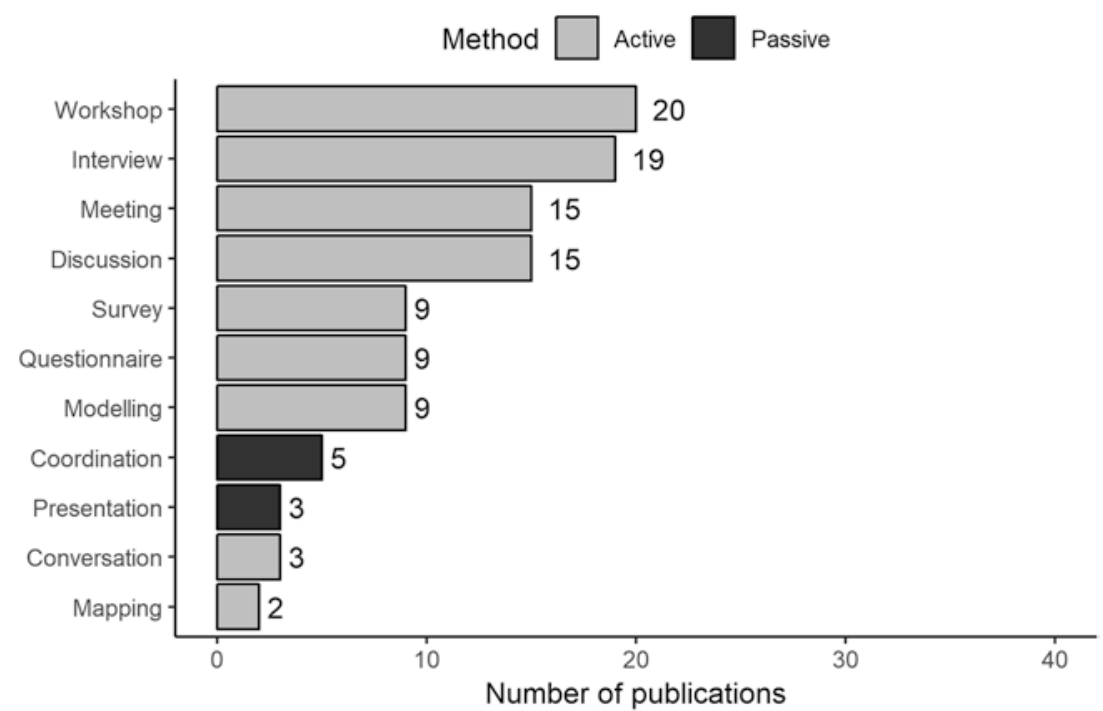

Fig. 2.5 Number of research publications with participation methods that occurred in coastal and marine fisheries research publications between 2000 and 2018; black lines represent the linear regression with $95 \%$ confidence intervals; grey area indicates the confidence band (Active: $\mathrm{R}^{2}=0.670, \mathrm{p}=0.0001895$; passive: $\mathrm{R}^{2}=0.00291$, $\mathrm{p}=0.8485$ )

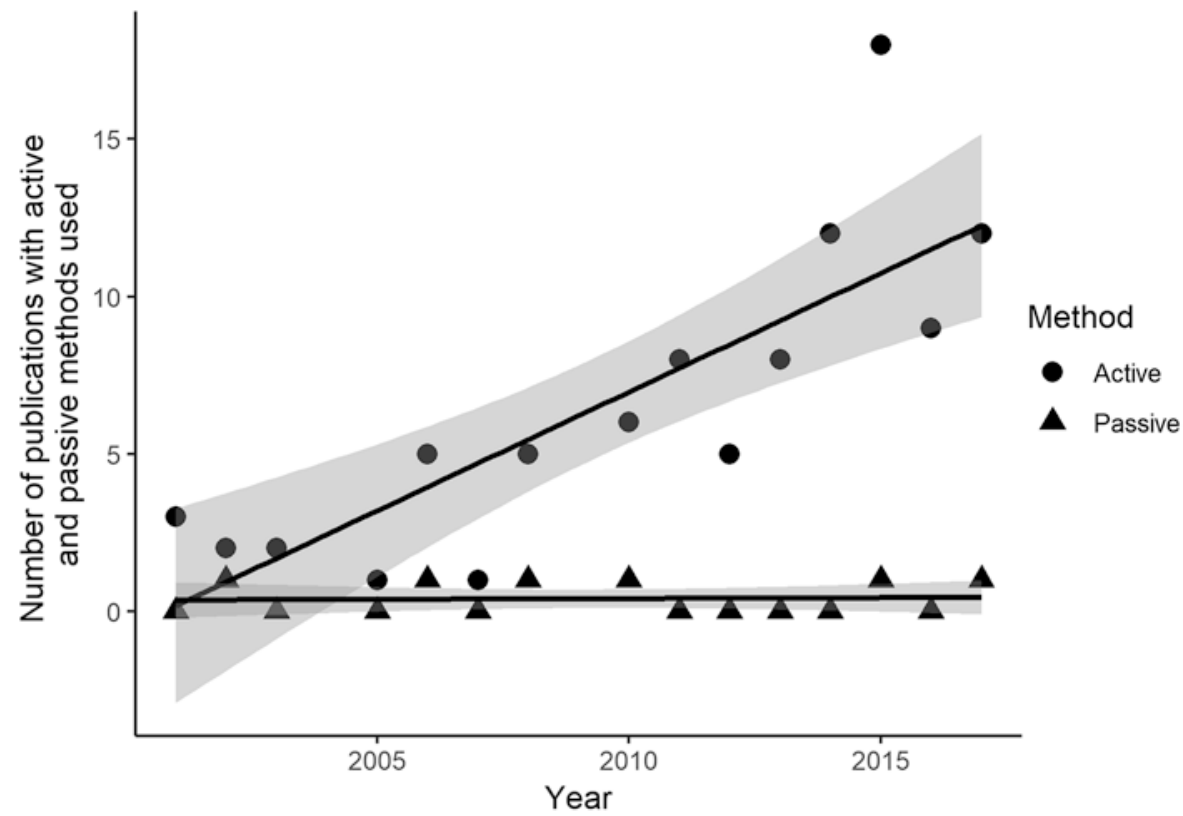

and Lazaro 2014), e.g. contractual, consultative, collaborative and collegiate (Biggs 1989), co-option, compliance, consultation, cooperation and co-learning (Kindon 2008). Kittinger (2013) used the term PAR, which is defined as a set of approaches related to the involvement of researchers and community members working collaboratively in the visioning, goal-getting, data gathering as well as assessment phases of research (Whyte et al. 1989; Kittinger 2013).

\subsubsection{Participatory Tools}

In contrast to the definition of participation, 45 publications focused on the description of participatory tools (Fig. 2.2b). We identified 11 participatory tools, which were divided into nine active and two passive participatory tools (Fig. 2.4). Active participation tools included workshops $(\mathrm{N}=20)$, interviews $(\mathrm{N}=19)$, meetings $(\mathrm{N}=15)$, discussions $(\mathrm{N}=15)$, questionnaires $(\mathrm{N}=9)$, surveys $(\mathrm{N}=9)$, modelling $(\mathrm{N}=19)$, conversation $(\mathrm{N}=3)$ and mapping $(\mathrm{N}=2)$. Coordination $(\mathrm{N}=5)$ and presentations $(\mathrm{N}=3)$ represented passive participation tools (Fig. 2.4).

We detected no changes in the number of publications over time using passive methods. In contrast, we found a significant increase in the number of case studies applying active methods with a peak in $2015(\mathrm{~N}=19)$ (Fig. 2.5).

Table 2.4 presents utilized tools and related sub-tools. Here, the highest number of sub-tools was presented by interviews, including sub-tools $(\mathrm{N}=14)$, e.g. semi-structured interview (e.g. Carr and Heyman 2012; Stöhr et al. 2014; Yates and Schoeman 2015; Rivera et al. 2017), unstructured interview (Hara et al. 2014) and key informant interview 
Table 2.4 List of active as well as passive participation tools and including sub-tools, described within 50 research publications presenting case studies in coastal and marine fisheries (as of May 2018) between 2000 and 2018

\begin{tabular}{|c|c|c|}
\hline & $\begin{array}{l}\text { Participation } \\
\text { tool }\end{array}$ & Participation sub-tool \\
\hline \multirow[t]{9}{*}{ Active } & Workshop & $\begin{array}{l}\text { Stakeholder workshop, 1-day } \\
\text { workshop, 2-day workshop, } \\
\text { participatory workshop, structured } \\
\text { stakeholder workshop, value workshop, } \\
\text { gaming workshop }\end{array}$ \\
\hline & Meeting & $\begin{array}{l}\text { Roundtable meeting, joint planning } \\
\text { meeting, information meeting, } \\
\text { face-to-face meetings, working group } \\
\text { meeting, plenary meeting, group } \\
\text { meeting, sub-group meeting, } \\
\text { stakeholder group meeting, } \\
\text { management group meeting }\end{array}$ \\
\hline & Interview & $\begin{array}{l}\text { Structured interview, semi-structured } \\
\text { interview, unstructured interview, } \\
\text { personal interview, key informant } \\
\text { interview, in-depth interview, one-on- } \\
\text { one interview, face-to-face interview, } \\
\text { structured face-to-face interview, } \\
\text { face-to-face semi-structured interview, } \\
\text { open-end face-to-face interview, formal } \\
\text { interview, informal interview, } \\
\text { qualitative interview }\end{array}$ \\
\hline & Conversation & $\begin{array}{l}\text { Dialogue, informal conversation, } \\
\text { focused conversation }\end{array}$ \\
\hline & Discussion & $\begin{array}{l}\text { Group discussion, focus group, forum } \\
\text { discussion, open discussion, } \\
\text { stakeholder advisory panel }\end{array}$ \\
\hline & Questionnaire & $\begin{array}{l}\text { Structured interview questionnaire, } \\
\text { e-mail-based questionnaire, follow-up } \\
\text { questionnaire }\end{array}$ \\
\hline & Survey & $\begin{array}{l}\text { Large-scale interview survey, face-to- } \\
\text { face interview survey, online survey, in } \\
\text { situ survey, attitudinal survey }\end{array}$ \\
\hline & Modelling & $\begin{array}{l}\text { Tool, participatory modelling, Bayesian } \\
\text { belief network }\end{array}$ \\
\hline & Mapping & $\begin{array}{l}\text { Cognitive mapping, fuzzy cognitive } \\
\text { mapping }\end{array}$ \\
\hline \multirow[t]{2}{*}{ Passive } & Coordination & Voting, rating, evaluation \\
\hline & Presentation & Video, poster, exhibition, tableaux \\
\hline
\end{tabular}

(Eriksson et al. 2016). Meetings and workshops showed the second and third highest number of sub-tools. Here, meetings were presented, with sub-tools $(\mathrm{N}=10)$, e.g. roundtable meeting (Kerr et al. 2006), joint planning meeting (Kittinger 2013) and face-to-face meeting (Miller et al. 2010). However, workshops were shown, including sub-tools $(\mathrm{N}=7)$, e.g. stakeholder workshop (Eriksson et al. 2016; Burdon et al. 2018) and participatory workshop (Bojorquez-Tapia et al. 2016). Passive participation methods included coordination, with sub-tools $(\mathrm{N}=3$ ), e.g. voting (Miller et al. 2010; Thiault et al. 2017; Zengin et al. 2018), rating (Goetz et al. 2015), evaluation (Cox and Kronlund 2008) and presentation, including sub-tools $(\mathrm{N}=4)$, e.g. video (Clarke et al. 2002), poster (Kerr et al. 2006), exhibition (Kerr et al. 2006) and tableaux (Kerr et al. 2006). We also determined whether preparatory work was performed and described within the case studies under review. Among others, observations (Delaney et al. 2007; Granados-Dieseldorf et al. 2013; Trimble and Berkes 2013; Stöhr et al. 2014; Trimble and Lazaro 2014; Mabon and Kawabe 2015), fieldwork (Mabon and Kawabe 2015; Sampedro et al. 2017) and visits (Kerr et al. 2006) were carried out. Furthermore, newsletters (Kerr et al. 2006) and e-mails (Lorance et al. 2011) were sent out to call for participation within different stakeholder types. Moreover, telephone calls (Kerr et al. 2006) were made, and consultations took place, e.g. consultation with stakeholders (Cox and Kronlund 2008; Mapstone et al. 2008; Williams et al. 2011).

\subsubsection{Intention for Participation}

Within this review, we looked at the diversity of the intention for participation; we classified these intentions as types and sub-types (Table 2.5).

The intention types identification $(\mathrm{N}=20)$, with subtypes, e.g. target species (Fletcher 2005), ways of communication (Zengin et al. 2018), stakeholder characteristics (Bojorquez-Tapia et al. 2016; Kinds et al. 2016; Burdon et al. 2018) and assessment $(\mathrm{N}=12)$, with sub-types, e.g. management system (Lorance et al. 2011), knowledge (Carr and Heyman 2012) and data (Catedrilla et al. 2012) occurred most often (Fig. 2.6). Establishment $(\mathrm{N}=5)$, development $(\mathrm{N}=7)$, evaluation $(\mathrm{N}=7)$ and improvement $(\mathrm{N}=7)$ occurred moderately often (Fig. 2.6). Less widely used were analysis $(\mathrm{N}=3)$, definition $(\mathrm{N}=2)$, description $(\mathrm{N}=2)$ and feedback $(\mathrm{N}=2)$ (Fig. 2.6).

Establishment $(\mathrm{N}=10)$, assessment $(\mathrm{N}=7)$ and identification $(\mathrm{N}=7)$ had the most sub-types within the case studies under review. Improvement $(\mathrm{N}=5)$, development $(\mathrm{N}=4)$ and evaluation $(\mathrm{N}=4)$ showed a moderate diversity of subtypes, whereas feedback $(\mathrm{N}=2)$, e.g. feedback from stakeholders on the meeting (Dowling et al. 2008), as well as description $(\mathrm{N}=2)$, e.g. knowledge about socio-ecological systems (Gray et al. 2012) and management implications (Smith et al. 2001) presented the lowest diversity of sub-types.

\subsubsection{Reflection on the Joint Term Stakeholder and Participation}

In the final evaluation, we analysed the application of stakeholder participation as one term. We first evaluated whether 
Table 2.5 Types and associated sub-types of intentions for participation determined within 50 research publications focusing on stakeholder participation in coastal and marine fisheries from 2000 to 2018

\begin{tabular}{|c|c|}
\hline Type & Sub-type \\
\hline \multirow[t]{3}{*}{ Analysis } & Stakeholders' perception \\
\hline & Mental models \\
\hline & Management system \\
\hline \multirow[t]{7}{*}{ Assessment } & $\begin{array}{l}\text { Management system (e.g. adaptive } \\
\text { co-management, history of management } \\
\text { implementation) }\end{array}$ \\
\hline & Ideas of alternative livelihood \\
\hline & $\begin{array}{l}\text { Knowledge (e.g. fishers ecological knowledge), } \\
\text { perception and attitude of stakeholders }\end{array}$ \\
\hline & Method success \\
\hline & $\begin{array}{l}\text { Data (e.g. interviews, socioeconomic } \\
\text { characteristics) }\end{array}$ \\
\hline & Solution on regional level \\
\hline & $\begin{array}{l}\text { Effectiveness of collaboration between } \\
\text { stakeholders }\end{array}$ \\
\hline \multirow[t]{3}{*}{ Definition } & Criteria for evaluation \\
\hline & Objectives \\
\hline & Management implications \\
\hline \multirow[t]{2}{*}{ Description } & Knowledge of socio-ecological system (SES) \\
\hline & Management implications \\
\hline \multirow[t]{4}{*}{ Development } & Consensus-building \\
\hline & Comprehensive map \\
\hline & Stakeholder-driven scenarios \\
\hline & Criteria for participatory research \\
\hline \multirow[t]{10}{*}{ Establishment } & Co-management mechanism \\
\hline & Collective research agenda \\
\hline & Vision for future fisheries management \\
\hline & Comprehensive map of predicting fishing effort \\
\hline & Guidance for scientists \\
\hline & Scientific advice \\
\hline & Theory of causal mechanisms \\
\hline & Platform for information and decision-making \\
\hline & Stakeholder-driven scenarios \\
\hline & Clear and open views \\
\hline \multirow[t]{4}{*}{ Evaluation } & Mental models \\
\hline & Harvest policies \\
\hline & Results from interview (cross-checking) \\
\hline & Fishery and management system \\
\hline \multirow[t]{2}{*}{ Feedback } & Forecast content \\
\hline & Meeting \\
\hline \multirow[t]{7}{*}{ Identification } & $\begin{array}{l}\text { Stakeholders' characteristics (e.g. attitude, } \\
\text { perception, wishes, concerns, knowledge (local } \\
\text { ecological knowledge, fishers ecological } \\
\text { knowledge) }\end{array}$ \\
\hline & Information (e.g. socio-ecological) \\
\hline & Target species \\
\hline & $\begin{array}{l}\text { Objectives (e.g. criteria, uncertainties, drivers, } \\
\text { consequences, human dimensions, population } \\
\text { needs, reference points) }\end{array}$ \\
\hline & Weakness of fishery system \\
\hline & Range of quantifiable objectives and strategies \\
\hline & Ways of communication \\
\hline
\end{tabular}

Table 2.5 (continued)

\begin{tabular}{l|l}
\hline Type & Sub-type \\
\hline Improvement & $\begin{array}{l}\text { Stakeholder participation, relationships and } \\
\text { requirements }\end{array}$ \\
\cline { 2 - 2 } & Management \\
\cline { 2 - 2 } & Socio-economic drivers \\
\cline { 2 - 2 } & Data \\
\cline { 2 - 2 } & Website \\
\hline
\end{tabular}

stakeholder participation was used for doing research on stakeholders or if the case studies were conducted with the participation of stakeholders. Overall, 24 publications utilized the term stakeholder participation for the research on stakeholders (research tool); 21 publications used stakeholder participation in their conducted case study (participation tool). Within five case studies, it was uncertain whether stakeholder participation was used or not (Fig. 2.2c).

In the case study conducted by Kinds et al. (2016), the term stakeholder participation was used to describe the development of a sustainability tool with the direct input from users, i.e. fishers. Here, the wishes and preferences of stakeholders were recognized and implemented to improve the output of the utilized tool but not to influence decisionmaking processes (research tool). Rivera et al. (2017) carried out semi-structured interviews to assess stakeholders' perceptions to identify management, biology and socioeconomic drivers related to the gooseneck barnacle fishery in Spain. This case study used the term stakeholder participation, but no influence on the management by stakeholders was mentioned (research tool). Tiller et al. (2015) applied an integrated approach of two methods, Systems Thinking and Bayesian Belief Networks, to elicit stakeholders' opinions through participatory engagement. Both methods were used to investigate, e.g. how stakeholders perceive the ecological system in the Trondheimsfjord, but with no further impact on decision-making processes (research tool). Through the method of Systems Thinking, shared mental models of the ecological system in the Trondheimsfjord were developed. Bayesian Belief Networks were further used for exploration of the priority issues as well as to represent causal relationships between defined variables. In contrast, Trimble and Berkes (2013) presented the concept of participatory research, i.e. involving fishers and policymakers as well as managers among other stakeholders in the case of a sea lion population and a fishery in Uruguay. Within this case study, stakeholders, e.g. fishers had an impact on decision-making processes related to the management of the sea lion population (participation tool). Williams et al. (2011) conducted a case study based on the participation of commercial fishers, defining various alternative management strategies related to the Torres Strait Finfish Fishery (TSFF) in Australia, i.e. sea- 

types of intention for participation occurred in 50 research publication looking at coastal and marine fisheries (as of May 2018)
Fig. 2.6 Frequency at which

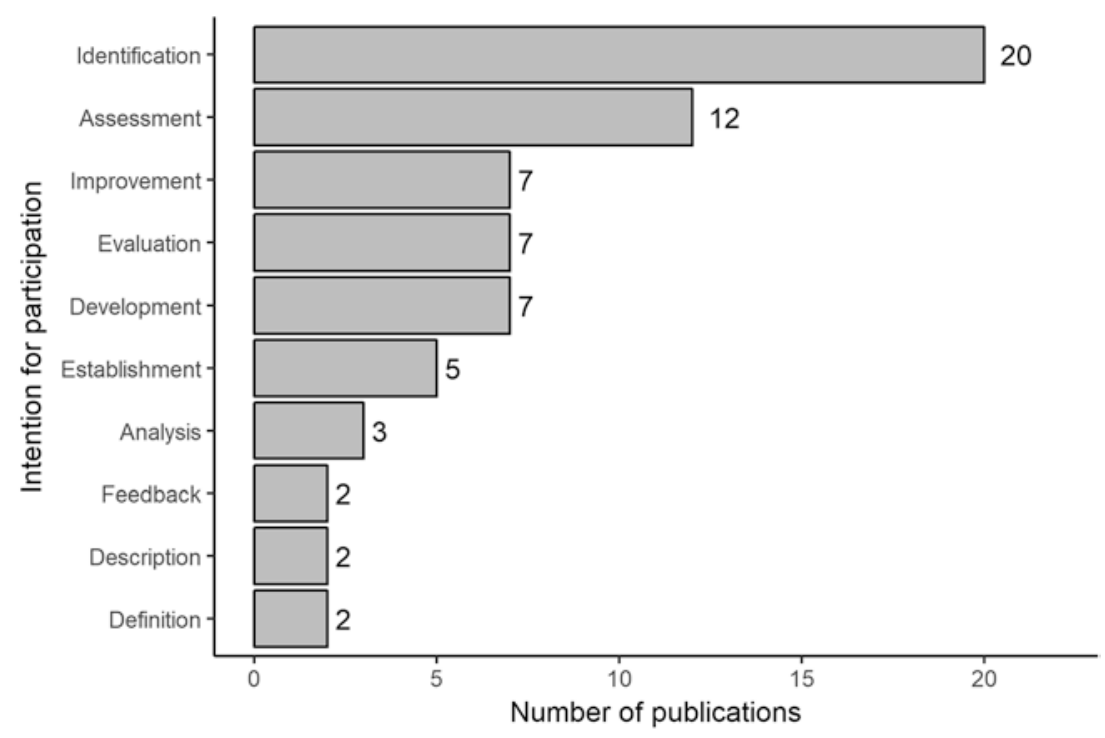

\subsubsection{Stakeholder}

sonal closure, large minimum capture size, to provide a framework for impartial evaluation of management strategy performance (participation tool). In addition, Stöhr et al. (2014) described the concept of stakeholder participation by evaluating two case studies; only the Polish case had a coastal and marine focus. Within this case study, roundtables were applied to create a multi-stakeholder platform with the objective of informing and influencing decision-making processes (participation tool).

\subsection{Discussion}

In total, 50 case studies focusing on stakeholder participation in coastal and marine fisheries were identified and reviewed. Most of the publications did not define the term stakeholder or participation or described a systematical approach of selecting stakeholders. Moreover, stakeholder participation was mentioned in all 50 publications, but only half of the case studies involved stakeholders in the process of participation.

It should be noted that we could only show what has been described in the publications under review; here, we did not present a comprehensive overview of all relevant stakeholder types that would be possible in the respective contexts.

\subsubsection{Term Definition and Stakeholder Analysis}

Four case studies defined the term stakeholder and, thus, showed a scientific examination of potentially concerned stakeholder types; 15 publications used a systematic description of how stakeholders were identified. The other publications used intuitive decisions to identify relevant stakeholders in their case study. This led to the fact that, related to our research focus on coastal and marine fisheries, the stakeholder type 'fishery' was mostly involved; 'public' stakeholders were only rarely involved.

All case studies included 'fishery' as a stakeholder type. Therefore, we proposed that 'fishery' is seen as the main stakeholder type in coastal and marine fisheries research. Mahon et al. (2003) supported this thesis literally by writing that within the conducted case study, the primary stakeholders are the fishers. In some publications, 'fishery' was even the only stakeholder type considered. Although at first sight this realization might seem logical, it can be discussed; fisheries are harvesting a common resource and, therefore, do not necessarily contribute towards the sustainable exploitation of coastal and marine fisheries resources, as most case studies consider stakeholder participation as a way of implementing more sustainable fisheries management (e.g. Wilson et al. 2003; Thiault et al. 2017). Although not all forms of fisheries were considered unsustainable, artisanal fisheries, for example, were often associated with having a small impact on fish stocks (Carvalho et al. 2011) but have been proven to cause impact beyond sustainable levels (Pomeroy 
2012); they also deal with other sustainability issues such as bycatch of birds (Almeida et al. 2017).

Within our review, we used the category 'others' to classify stakeholders that did not fit into any other category. This fact shows very clearly that, on the one hand, there is great diversity of stakeholder types within the field of coastal and marine fisheries research; on the other hand, it describes existing discrepancies in the understanding of the term definition and the classification of corresponding stakeholders. We, therefore, suggest to clearly define the term stakeholder as well as to discuss their role in the specific context of the conducted case study. Although Tiller et al. (2015) criticized the stakeholder definition by Freeman (2010) as too broad, they did not give a clear term definition either in their own case study. We assume that there is a high risk of excluding relevant stakeholder types, when not applying a term definition for stakeholder as well as not using a stakeholder analysis tool to ensure that relevant stakeholders are approached. This could lead to the fact that, for example, no local ecological knowledge or fisheries ecological knowledge would be recorded for the corresponding case study, which is important inter alia for better understanding the marine ecology and making results more convincing for resource users (Davis et al. 2004) and, therefore, increase the legitimacy of resource management (Aanesen et al. 2014). It is not important to include all stakeholders available but to choose them carefully according to the objectives of the case study, which means applying a stakeholder analysis approach (Durham et al. 2014).

\subsubsection{Stakeholder Clusters}

We showed, with using MCA, that 'eNGO', 'politics' and 'science' are often addressed together within the strongest dimension. Therefore, we could conclude that these stakeholder types were considered important within many conducted case studies. This dimension described stakeholders that deal with a rather theoretical side in the field of fishery, i.e. in the form of regulations, research or campaigns. It can be argued that these stakeholders contributed towards research and management as well as towards different forms of sustainability; therefore, 'eNGO', 'politics' and 'science' have a more sustainability-oriented attitude. This finding is strongly supported by Aanesen et al. (2014); they concluded that, under the European Common Fisheries Policy, authorities, scientists and NGOs have a similar perspective on fisheries management. This is rather obvious for 'eNGO', as they are seen as representing the ecological sustainability. By contrast, 'politics' could be interpreted as representing the population, i.e. this stakeholder group acts in the interest of the sustainability of food, but is also driven by the eco- nomic sustainability. 'Science' could be seen as the representative and provider of research. We suggest that these stakeholder groups have a general interest in sustainable management and are not directly or financially dependent on the resource fish. Of course, it can be argued that certain jobs of eNGOs, scientists or politicians depend on the debate as well as on the public interest in fish and fishery. But this argument is to be classified as marginal in this context. One reason is that fish is one of the main protein sources for humans; even if the resource fish would shrink, it will always be of interest for certain stakeholder types.

In our sample of publications, 'politics', 'eNGO' and 'science' were mentioned most frequently after 'fishery'. For that reason, we can assume that these three stakeholder groups are deemed the second most important stakeholder groups. It can be discussed that 'politics', 'eNGO' and 'science' should have at least an equally strong stake in fisheries research compared to 'fishery'.

Another group displayed by MCA is formed by 'related industry' and 'recreational fishery'. Both stakeholder groups mostly occurred in the second strongest dimension, which can be interpreted as stakeholders who are handling the resource fish and, therefore, dealing with it in a practical way. Although they also have an interest in sustainable management, they, unlike 'science', 'politics' and 'eNGO', depend financially (especially 'fishery') or mentally (e.g. 'fishery' and 'recreational fishery') on the resource fish. Therefore, profit or benefit orientation can be seen as another factor describing dimension 2. This is supported by the fact that the two groups (dimension 1: sustainability vs. dimension 2: dependence) discussed are placed far away from each other in the MCA. Both stakeholder groups cannot be seen as independent from each other as their decisions are influencing each other's actions, e.g. if political regulations or campaigns led by 'eNGOs' resulted in decreasing harvest rates of fish, commercial and recreational fishers are negatively affected. We take a critical look at these stakeholder groups, as they are presented apart from each other in the conducted MCA and, therefore, are not engaged equally in the reviewed case studies. We recommend to engage these stakeholder types more equally. The cooperation between fishery-related stakeholders and scientists could lead to more informed stakeholders on both sides; therefore, a greater mutual understanding, trust as well as likelihood of long-lasting partnerships could be achieved (Hartley and Robertson 2006).

We showed that 'public' participation is relatively low in the field of coastal and marine fisheries research. This fact is reflected among other things in the low numbers of mention within the case studies. Here, 'public' as one stakeholder group contributed the least to the two strongest dimensions. 
On the one hand, the low involvement could be interpreted as a lack of interest. On the other hand, we argue that public stakeholders were not directly addressed within the publications. In relation to the definition we used to classify 'public', it can be critically discussed that 'eNGOs' could also be seen as representatives of the civil society (e.g. Pristupa et al. 2016) and community leaders could include voted politicians (Rivera et al. 2017). But we decided to stick to the stakeholders as they were mentioned in the publications. The results showed that 'public' stakeholders are not part of any group; nevertheless, they dominated the weakest dimension and explained the high percentage of its variance.

Data from North American and European case studies resulted in different MCAs. This can be seen for example with 'recreational fishery'. Although this stakeholder type is part of the European Common Fisheries Policy, they are not considered as stakeholders in any of the case studies conducted in Europe. This is different for North American case studies; here 'recreational fishery' was seen as a stakeholder type. Even if this analysis gave only a small insight into the topic, regional differences related to stakeholder types could already be made clear here. These differences cannot be explained by different management systems, because both in Europe and in North America recreational fisheries are included in their regulations; the results further need to be investigated. Furthermore, we assumed different emphases of stakeholder types; therefore, when applying MCA to different regions, different interpretations of the dimensions have to be made. However, the small sample size for regional MCAs could reduce the significance of such interpretations.

Based on the application and analysis of the term stakeholder, we conclude that there were only a few case studies that critically assessed the concept of stakeholders. Nevertheless, our results provide an insight into how stakeholders were seen in the field of coastal and marine fisheries research, i.e. who is considered as important and which stakeholders are often consulted together.

\subsubsection{Participation}

\subsubsection{Term Definition and Typologies}

Out of 50 case studies focusing on the topic stakeholder participation in coastal and marine fisheries, only seven case studies defined the term participation or a participationrelated term. However, there is a wide variety of definitions and typologies of stakeholder participation in the literature.

Green and Hunton-Clarke (2003) represented different typologies of participation regarding environmental decision- making. Five concepts of participation were listed and defined to increase the level of involvement. On the one hand, Arnstein's (1969) concept of stakeholder participation was described; this concept is based on eight levels: nonparticipation (manipulation and therapy), tokenism (informing, consultation and placation) and citizen power (partnership, delegated power and citizen control) (Luyet et al. 2012). On the other hand, the participation concept by Pretty and Shah (1994) was presented. Here, participation is classified by using six steps: passive participation, participation by information giving, participation by consultation, functional participation, interactive participation and self-mobilization. In Pristupa et al. (2016), participation was also described by the level of stakeholder involvement, but with regard to the concept of Arnstein (1969) and Pretty and Shah (1994), no further explanation was given of the different levels of participation in this case study.

In addition to Green and Hunton-Clarke (2003), Reed (2008) reviewed different typologies on stakeholder participation for environmental management. In this literature review, he defined the following typologies on which participation is based: (i) degrees of participation (e.g. Arnstein 1969), (ii) nature of participation (Rowe and Frewer 2000), (iii) theoretical basis (e.g. Thomas 1993) and (iv) participation based on objectives for which participation is used (e.g. Okali et al. 1994) (Reed 2008). The fourth typology was used in the case studies by Sampedro et al. (2017) and Tiller et al. (2015). Here, participation was described as the use for planning or co-management experiences (Sampedro et al. 2017) and as the strategy for involving stakeholders in decision-making processes (Tiller et al. 2015). Related to the case studies under review, we would add a fifth typology of participation, i.e. participation based on the opportunity to participate in relation to resources. Brzezinski et al. (2010) described and defined participation as a role benefiting participating stakeholders based on money and geographical proximity. The case study showed the connection between geographical closeness and the level of attendance, i.e. the closer stakeholders were to meetings, the higher was their level to attend at those meetings (Brzezinski et al. 2010).

As NOAA (2015) generalized, there is no 'one-size-fitsall' approach or definition of participation; the implementation and the process of participation is dependent on several aspects, e.g. issue at hand, stakeholders, geography, schedules, as well as on time frames. Furthermore, Green and Hunton-Clarke (2003) recommended selecting the type of participation suitable for the situation or the problem that needs to be solved. We argue, to create a successful resource management and increase the acceptance of management 
measures by resource users, a well thought out participation approach is essential with regard to the sustainable use of coastal and marine resources.

\subsection{Conclusion}

Stakeholder participation is and will continue to be of central importance when it comes to the management of ecosystems and its resources. Although our findings showed clear tendencies in stakeholder participation, they also opened several other questions.

The grouping of 'science', 'eNGO' and 'politics' was discussed critically, especially 'public', 'recreational fishery' and 'related industry' were presented far away in the MCA. We suggest that these groups should not be seen as opposed to each other but be included in a more integrated way in participatory research projects. Low involvement of 'public' stakeholders and their contribution towards decisions should be further discussed, because wild fish is widely seen and communicated as a common pool resource. As a consequence, 'public' stakeholders, i.e. representatives of the common, should also have a stake in the management of the resource also since ecosystem changes will affect all citizens.

We advise to include different stakeholder types and take advantages of their different experiences, although we recognize that pragmatic and methodological reasons such as the willingness to participate can constrain these efforts. While our analysis has not been profoundly focused on regional differences, it should be noted that there are regional differences between the relationships between and the contributions of stakeholders. Even though only done marginally in our analysis, dividing the data into different regions showed that relationships and contributions varied between stakeholder types. For further research, we advise to set a regional focus on stakeholder participation and discuss it under the light of different management regulations.

Although we presented stakeholder types carefully deducted from the texts, the perception of these types is always at risk to change throughout a paper review process. Soma and Vatn (2014), e.g. separated the role of stakeholders and citizens in participatory processes, not discussing citizens as stakeholders but also plead for the involvement of citizens in natural resource management; therefore, we categorized these stakeholders in the same manner.

Research projects and stakeholder participation processes apart from research projects are mostly restricted by resources, e.g. time, money (Angelstam et al. 2013), capacity (Mackinson et al. 2011), expertise, i.e. expertise of social researchers and the availability of researchers as well as of stakeholders in general. These limitations can be a reason for not including a systematic discussion of the term stakeholder or a scientific stakeholder analysis. Because only a few of the reviewed publications described a definition or an approach of analysing stakeholders, we conclude that there were also limitations of integration, i.e. the involvement of social scientists in the process of stakeholder participation. In addition, it is of great advantage to know which typology and degree of participation have been used and benefit from experienced advantages as well as disadvantages of applied methods (Luyet et al. 2012). This way, conflicts can be avoided and stakeholder participation can be implemented in a better way.

In times of interdisciplinary (Repko et al. 2011) as well as transdisciplinary research (Häberli et al. 2001), and the intention of further improving science in general, we call for an increasing involvement of social scientists regarding the processes of stakeholder participation in coastal and marine fisheries research; more funding opportunities are needed to support this kind of integrated research field.

Our review clearly showed that many different definitions of stakeholder participation exist, and so researchers need to be careful when they examine which one is applicable towards their research goal. Related to this great diversity of stakeholder participation definitions, we will not present the definition. Nevertheless, we advise to conduct a critical analysis of stakeholder types as well as on participation tools at the beginning of a new research project with the aim of involving stakeholders related to decisionmaking processes. Durham et al. (2014) and NOAA (2015) offer well-applicable and explained stakeholder participation guides, which can be applied at the process start of the project. A systematic and comprehensible consultation of the methods presented in these guides can lead to an improved transparency of the results and decreases the potential of overlooking stakeholder groups or participatory tools that fit the research goal.

Acknowledgements HS is funded by the PhD Scholarship Programme of the German Federal Environmental Foundation (Deutsche Bundesstiftung Umwelt, Osnabrück; no. 2017/480).

\section{Appendix}

This article is related to the YOUMARES 9 conference session no. 2: 'Towards a sustainable management of marine resources: integrating social and natural sciences.' The original Call for Abstracts and the abstracts of the presentations within this session can be found in the Appendix 'Conference Sessions and Abstracts', Chapter '2 Towards a sustainable management of marine resources: integrating social and natural sciences', of this book. 


\section{Supplementary Material}

Figure 2.A1 Percentage of explained variance calculated by multiple correspondence analysis (MCA) showing the variance of stakeholder types within 50 research publications presenting 50 research publications of case studies in coastal and marine fisheries (as of May 2018)
Fig. 2.A2 Panels $\mathbf{b}$ and $\mathbf{c}$ of the visualization of the correlation between dimension 2 (Dim2) and dimension 3 (Dim3) (b) as well as dimension 1 (Dim1) and dimension 3 (Dim3) (c) towards the variance of stakeholder types within in 50 research publications of case studies in coastal and marine fisheries (as of May 2018) using multiple correspondence analysis (MCA); (b) $21.8 \%$ of variance were explained; here 'recreational fishery' and 'related industry' were focused. (c) Less variance $(17.7 \%)$ was explained; 'public' was the dominant stakeholder type

\section{Scree plot}

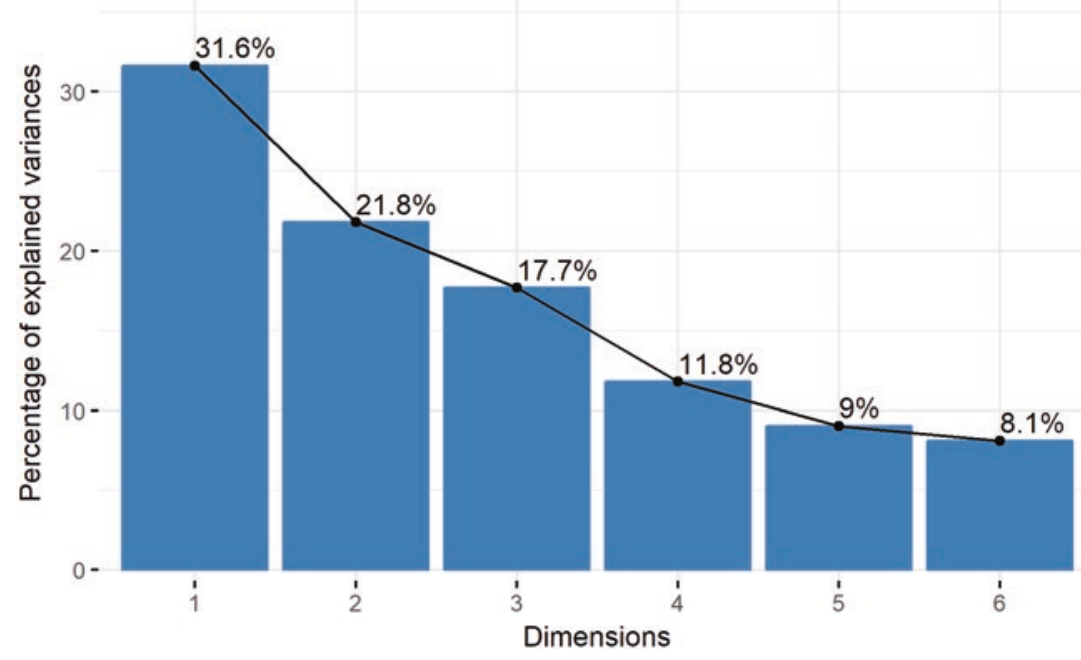

b Variable categories - MCA

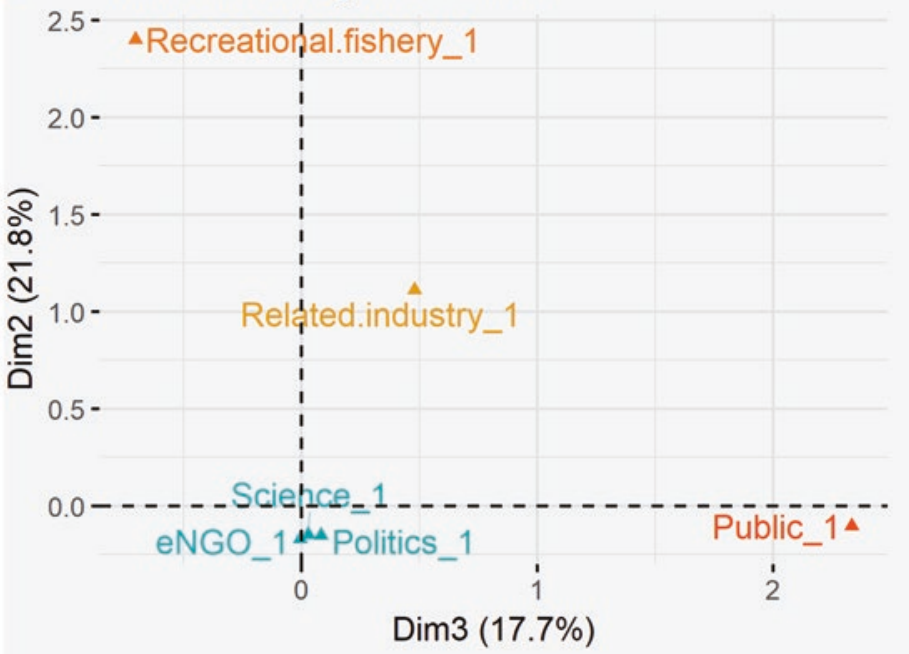

c Variable categories - MCA

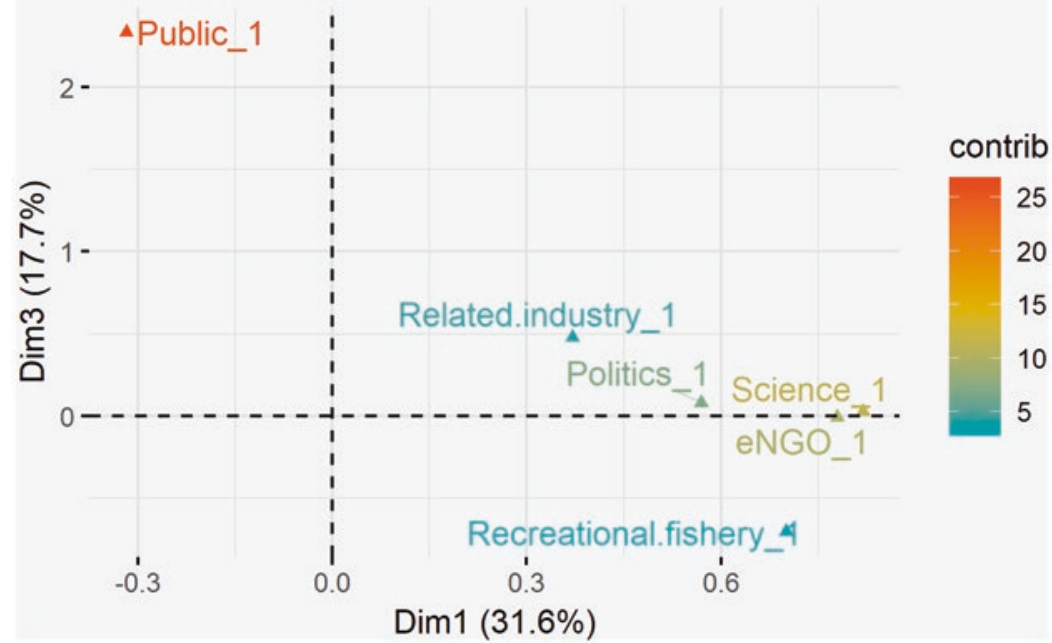


Figure 2.A3 Visualization of multiple correspondence analysis (MCA) results for case studies conducted in

North America; here correlation between dimension 1 (Dim1), dimension 2 (Dim2) and dimension 3 (Dim3) is presented. (a) strong contribution was shown by 'science', 'eNGO' and 'politics'; 'related industry' and 'recreational fishery' were displayed in the negative area; (b) strong contribution was presented by 'science', 'eNGO' and 'politics'. (c)

'Public' was the dominant stakeholder type a Variable categories - MCA

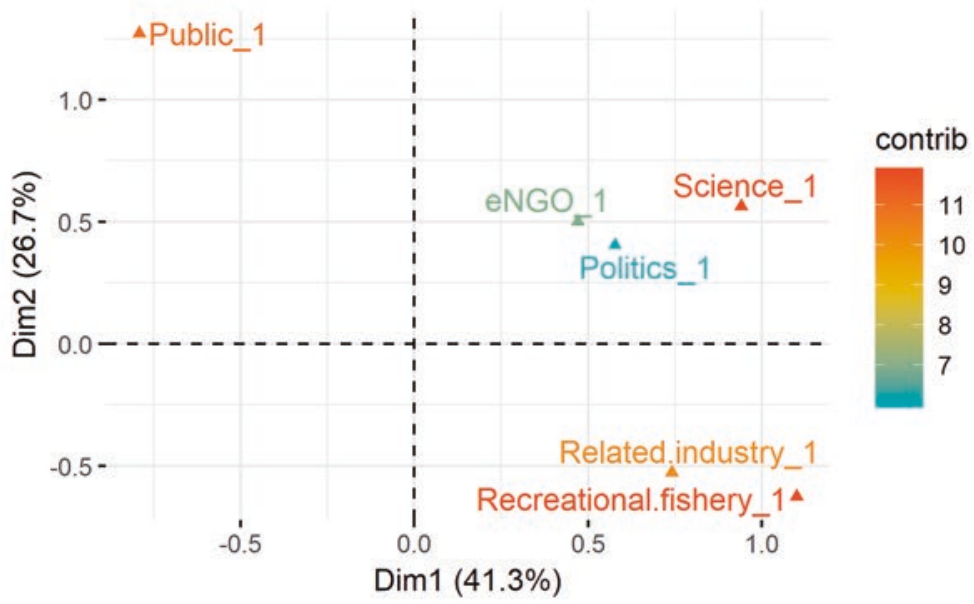

b Variable categories - MCA

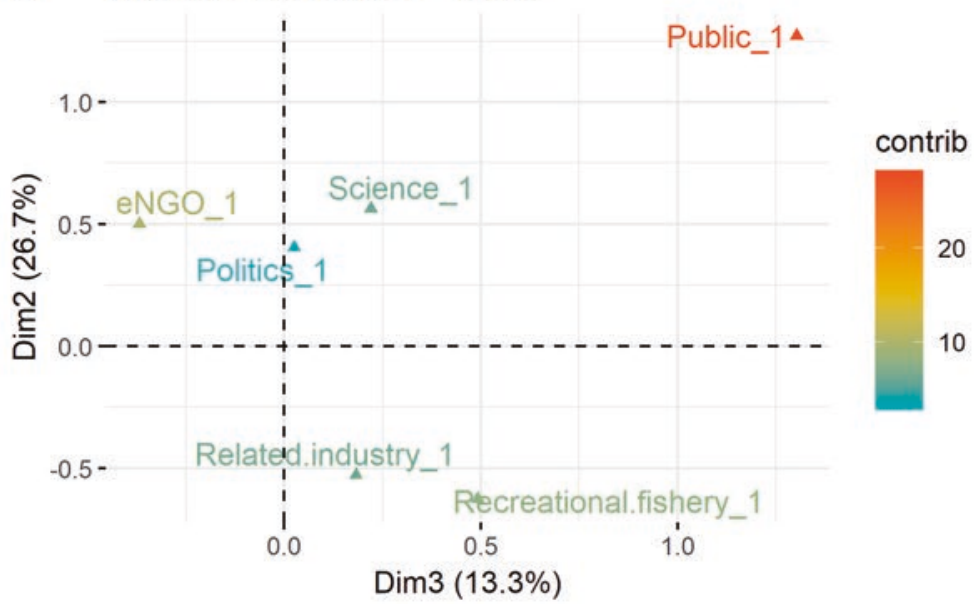

c Variable categories - MCA

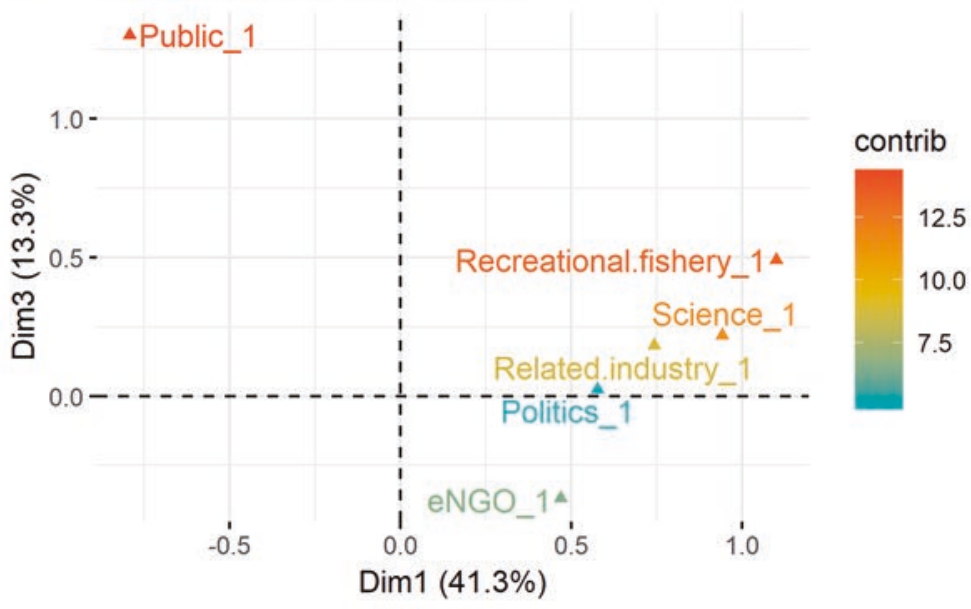


Figure 2.A4 Visualization of multiple correspondence analysis (MCA) results for research publications of European case studies in coastal and marine fisheries (as of May 2018); here correlation between dimension 1 (Dim1), dimension 2 (Dim2) and dimension 3 (Dim3) is presented. (a), (b) 'Related industry', 'public', 'science' and 'eNGO' were grouped together; 'politics' was rather set apart. (c) 'Politics' was the dominant stakeholder type

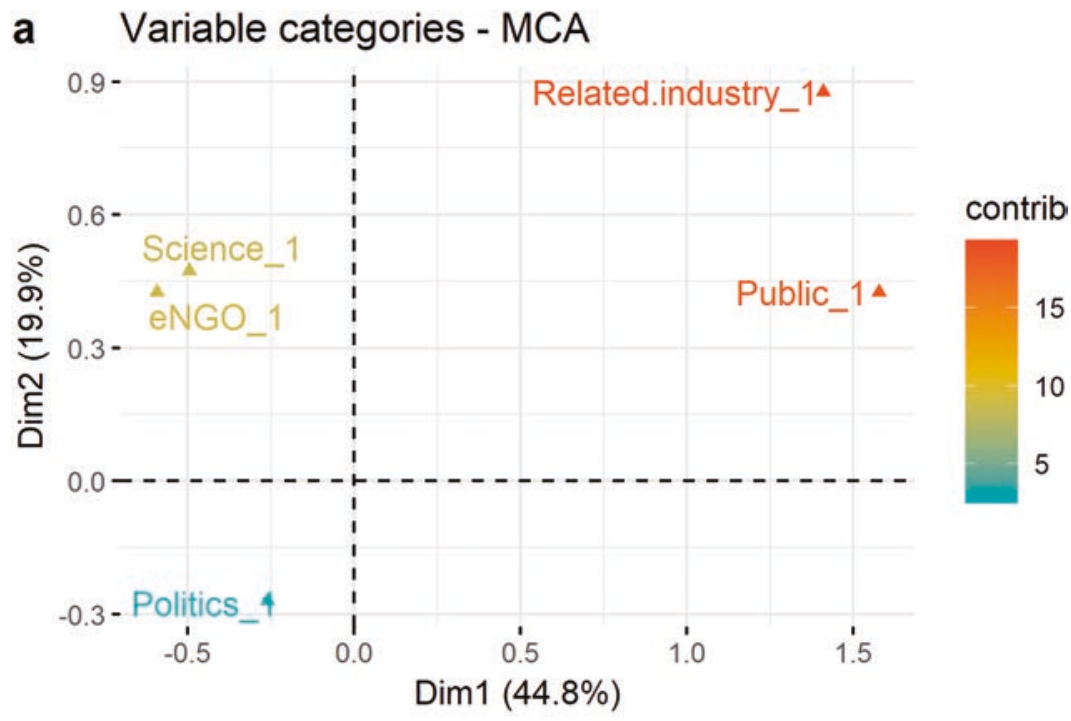

b Variable categories - MCA

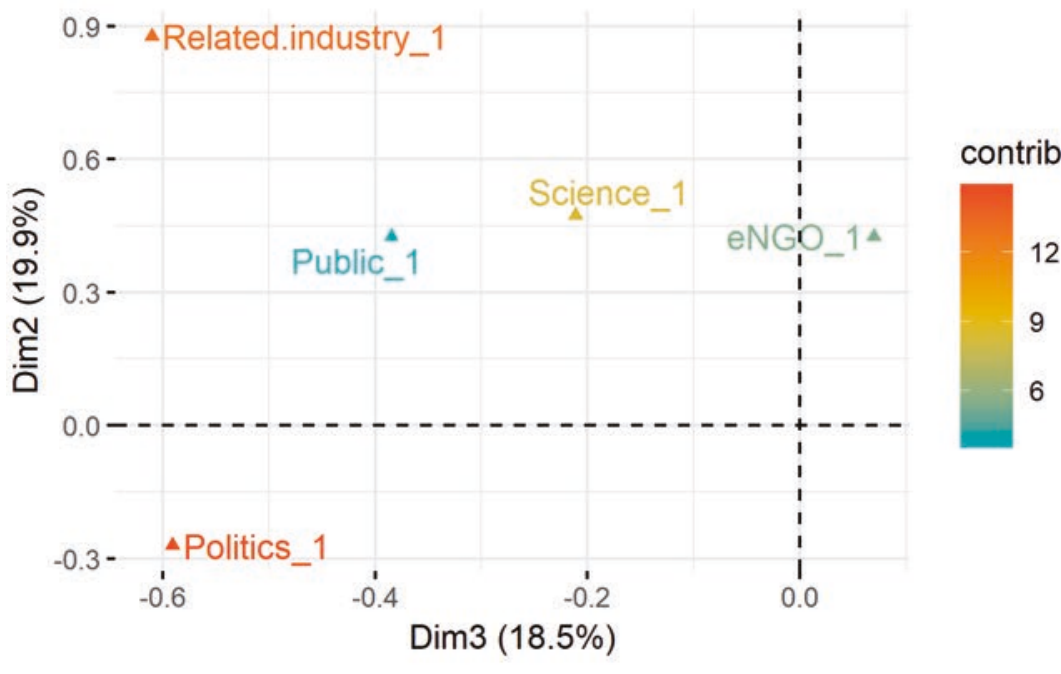

c Variable categories - MCA

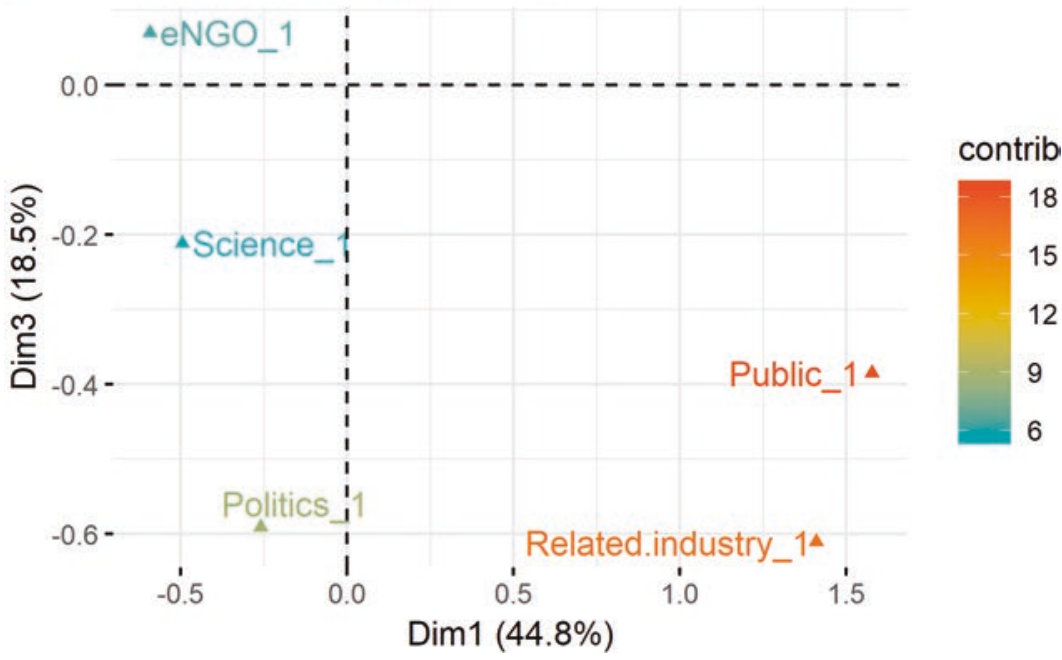


Table 2.A1 Contribution of variables, i.e. stakeholder types (measured in \%) towards five dimensions using multiple correspondence analysis (MCA); stakeholder types, i.e. science, politics, eNGO, recreational fisheries, related industry and public occurred within 50 research publications presenting case studies in coastal and marine fisheries (as of May 2018)

\begin{tabular}{l|l|l|l|l|l}
\hline & Dim 1 & Dim 2 & Dim 3 & Dim 4 & Dim 5 \\
\hline Science & 35.37 & 1.69 & 0.07 & 0.38 & 0.28 \\
\hline Politics & 27.89 & 2.88 & 1.02 & 36.32 & 19.43 \\
\hline eNGO & 29.59 & 2.06 & 0.01 & 33.62 & 9.77 \\
\hline Recreational fishery & 2.87 & 48.90 & 5.20 & 10.58 & 32.44 \\
\hline Related industry & 3.41 & 44.34 & 10.16 & 11.79 & 30.04 \\
\hline Public & 0.87 & 0.13 & 83.54 & 7.31 & 8.04
\end{tabular}

Table 2.A2 List of results related to the literature review focusing the topic stakeholder participation in the field of coastal and marine fisheries (type of stakeholder: $\mathrm{S}=$ science, $\mathrm{PO}=$ politics, $\mathrm{E}=\mathrm{eNGO}, \mathrm{F}=$ fisheries, $\mathrm{RF}=$ recreational fisheries, $\mathrm{RI}=$ related industry, $\mathrm{PU}=$ public, $\mathrm{O}=$ others; participatory method: MET = meeting, WOR $=$ workshop, DIS $=$ discussion, $\mathrm{INT}=$ interview, $\mathrm{QUE}=$ questionnaire, $\mathrm{SUR}=$ survey, $\mathrm{CON}=\mathrm{con}-$ versation, $\mathrm{MOD}=$ modelling, $\mathrm{MAP}=$ mapping, $\mathrm{PRE}=$ presentation, $\mathrm{COO}=$ coordination $)$

\begin{tabular}{|c|c|c|c|c|c|c|c|c|}
\hline Author & Continent & Country & $\begin{array}{l}\text { Definition of } \\
\text { stakeholder? }\end{array}$ & $\begin{array}{l}\text { Type of } \\
\text { stakeholder }\end{array}$ & $\begin{array}{l}\text { Stakeholder } \\
\text { analysis } \\
\text { approach? }\end{array}$ & $\begin{array}{l}\text { Definition of } \\
\text { participation? }\end{array}$ & $\begin{array}{l}\text { Description of } \\
\text { participatory } \\
\text { method? }\end{array}$ & $\begin{array}{l}\text { Which } \\
\text { methods } \\
\text { has been } \\
\text { used? }\end{array}$ \\
\hline $\begin{array}{l}\text { Appeldoorn } \\
(2008)\end{array}$ & $\begin{array}{l}\text { North } \\
\text { America }\end{array}$ & USA & & $\mathrm{F}, \mathrm{O}$ & & & & \\
\hline $\begin{array}{l}\text { Bitunjac et al. } \\
\text { (2016) }\end{array}$ & Europe & Adria & & $\mathrm{S}, \mathrm{PO}, \mathrm{E}, \mathrm{F}$ & $\mathrm{x}$ & & $\mathrm{x}$ & DIS \\
\hline $\begin{array}{l}\text { Bojorquez- } \\
\text { Tapia et al. } \\
(2017)\end{array}$ & $\begin{array}{l}\text { North } \\
\text { America }\end{array}$ & Mexico & & $\begin{array}{l}\text { S, PO, E, } \\
\text { F, RI }\end{array}$ & & & $\mathrm{x}$ & $\begin{array}{l}\text { WOR, } \\
\text { MOD }\end{array}$ \\
\hline $\begin{array}{l}\text { Brzezinski } \\
\text { et al. (2010) }\end{array}$ & $\begin{array}{l}\text { North } \\
\text { America }\end{array}$ & USA & $\mathrm{x}$ & E, F & & $\mathrm{x}$ & & \\
\hline $\begin{array}{l}\text { Burdon et al. } \\
\text { (2018) }\end{array}$ & Europe & $\begin{array}{l}\text { Denmark, } \\
\text { Germany }\end{array}$ & & $\mathrm{E}, \mathrm{F}, \mathrm{O}$ & & & $\mathrm{x}$ & $\begin{array}{l}\text { WOR, } \\
\text { DIS, INT }\end{array}$ \\
\hline $\begin{array}{l}\text { Butler et al. } \\
\text { (2015) }\end{array}$ & Europe & Scotland & & $\mathrm{PO}, \mathrm{F}, \mathrm{O}$ & $\mathrm{x}$ & & $\mathrm{x}$ & INT \\
\hline $\begin{array}{l}\text { Carr and } \\
\text { Heyman (2012) }\end{array}$ & $\begin{array}{l}\text { North } \\
\text { America }\end{array}$ & USA & & PO, E, F, O & & & $\mathrm{x}$ & INT, QUE \\
\hline $\begin{array}{l}\text { Catedrilla et al. } \\
\text { (2012) }\end{array}$ & Asia & Philippines & & $\mathrm{F}$ & $\mathrm{x}$ & & $\mathrm{x}$ & DIS, INT \\
\hline $\begin{array}{l}\text { Clarke et al. } \\
(2002)\end{array}$ & Asia & $\begin{array}{l}\text { China, Hong } \\
\text { Kong }\end{array}$ & & $\mathrm{F}$ & & & $\mathrm{x}$ & $\begin{array}{l}\text { MET, } \\
\text { DIS, PRE }\end{array}$ \\
\hline Cleland (2017) & Asia & Philippines & & $\begin{array}{l}\text { PO, E, F, } \\
\text { RI }\end{array}$ & & & $\mathrm{x}$ & WOR \\
\hline $\begin{array}{l}\text { Coelho Dias da } \\
\text { Silva et al. } \\
(2010)\end{array}$ & $\begin{array}{l}\text { South } \\
\text { America }\end{array}$ & Brazil & & $\mathrm{F}, \mathrm{O}$ & & & $\mathrm{x}$ & MET, DIS \\
\hline $\begin{array}{l}\text { Cox and } \\
\text { Kronlund } \\
(2008)\end{array}$ & $\begin{array}{l}\text { North } \\
\text { America }\end{array}$ & Canada & & F, RI & & & $\mathrm{x}$ & $\mathrm{COO}$ \\
\hline $\begin{array}{l}\text { Delaney et al. } \\
\text { (2007) }\end{array}$ & Europe & NA & & S, PO, E, F & & & $\mathrm{x}$ & INT \\
\hline $\begin{array}{l}\text { Dowling et al. } \\
\text { (2008) }\end{array}$ & Australia & Australia & & $\mathrm{S}, \mathrm{PO}, \mathrm{O}$ & & & $\mathrm{x}$ & MET, DIS \\
\hline $\begin{array}{l}\text { Eriksson et al. } \\
\text { (2016) }\end{array}$ & $\begin{array}{l}\text { Asia / } \\
\text { Africa }\end{array}$ & $\begin{array}{l}\text { Indonesia, } \\
\text { Philippines, } \\
\text { Solomon Islands, } \\
\text { Tanzania }\end{array}$ & & $\begin{array}{l}\text { S, PO, E, } \\
\text { F, PU, O }\end{array}$ & & & $\mathrm{x}$ & $\begin{array}{l}\text { WOR, } \\
\text { DIS, INT, } \\
\text { SUR }\end{array}$ \\
\hline $\begin{array}{l}\text { Eveson et al. } \\
\text { (2015) }\end{array}$ & Australia & Australia & & F & & & $\mathrm{x}$ & DIS, SUR \\
\hline $\begin{array}{l}\text { Field et al. } \\
\text { (2013) }\end{array}$ & Africa & South Africa & & $\begin{array}{l}\text { S, PO, E, } \\
F, O\end{array}$ & & & & \\
\hline
\end{tabular}


Table 2.A2 (continued)

\begin{tabular}{|c|c|c|c|c|c|c|c|c|}
\hline Author & Continent & Country & $\begin{array}{l}\text { Definition of } \\
\text { stakeholder? }\end{array}$ & $\begin{array}{l}\text { Type of } \\
\text { stakeholder }\end{array}$ & $\begin{array}{l}\text { Stakeholder } \\
\text { analysis } \\
\text { approach? }\end{array}$ & $\begin{array}{l}\text { Definition of } \\
\text { participation? }\end{array}$ & $\begin{array}{l}\text { Description of } \\
\text { participatory } \\
\text { method? }\end{array}$ & $\begin{array}{l}\text { Which } \\
\text { methods } \\
\text { has been } \\
\text { used? }\end{array}$ \\
\hline Fletcher (2005) & Australia & Australia & & $\begin{array}{l}\text { S, PO, E, } \\
\text { RF, RI, O }\end{array}$ & & & $\mathrm{x}$ & WOR \\
\hline $\begin{array}{l}\text { Garza-Gil et al. } \\
\text { (2015) }\end{array}$ & Europe & Spain & & $\begin{array}{l}\text { S, PO, F, } \\
\text { RI }\end{array}$ & & & $\mathrm{x}$ & $\begin{array}{l}\text { QUE, } \\
\text { SUR }\end{array}$ \\
\hline $\begin{array}{l}\text { Goetz et al. } \\
(2015)\end{array}$ & Europe & Spain, Portugal & & $\mathrm{S}, \mathrm{F}, \mathrm{O}$ & & & $\mathrm{x}$ & $\begin{array}{l}\text { WOR, } \\
\text { QUE, } \\
\text { SUR, } \\
\text { COO }\end{array}$ \\
\hline $\begin{array}{l}\text { Granados- } \\
\text { Dieseldorf } \\
\text { et al. (2013) }\end{array}$ & America & Belize & & $\mathrm{PO}, \mathrm{F}, \mathrm{O}$ & & & & \\
\hline $\begin{array}{l}\text { Gray et al. } \\
\text { (2012) }\end{array}$ & $\begin{array}{l}\text { North } \\
\text { America }\end{array}$ & USA & & $\begin{array}{l}\text { S, PO, E, } \\
\text { F, RF, RI, } \\
\text { O }\end{array}$ & $\mathrm{x}$ & & $\mathrm{x}$ & MAP \\
\hline $\begin{array}{l}\text { Haapasaari } \\
\text { et al. (2013) }\end{array}$ & Europe & Central Baltic & $\mathrm{x}$ & $\mathrm{S}, \mathrm{PO}, \mathrm{E}, \mathrm{F}$ & & & $\mathrm{x}$ & MOD \\
\hline $\begin{array}{l}\text { Hara et al. } \\
(2014)\end{array}$ & Africa & South Africa & & F, RI & & $\mathrm{x}$ & $\mathrm{x}$ & $\begin{array}{l}\text { MET, } \\
\text { WOR, } \\
\text { INT }\end{array}$ \\
\hline $\begin{array}{l}\text { Kaiser and } \\
\text { Forsberg } \\
(2001)\end{array}$ & Europe & Norway & & $\begin{array}{l}\text { F, RI, PU, } \\
\text { O }\end{array}$ & & & $\mathrm{x}$ & WOR \\
\hline $\begin{array}{l}\text { Kerr et al. } \\
(2006)\end{array}$ & Europe & Scotland, UK & & $\begin{array}{l}\text { S, PO, E, } \\
\text { F, O }\end{array}$ & & & $\mathrm{x}$ & $\begin{array}{l}\text { MET, } \\
\text { INT, } \\
\text { QUE, } \\
\text { PRE }\end{array}$ \\
\hline $\begin{array}{l}\text { Kinds et al. } \\
(2016)\end{array}$ & Europe & Belgium & $\mathrm{x}$ & PO, E, F & $\mathrm{x}$ & & $\mathrm{x}$ & $\begin{array}{l}\text { DIS, INT, } \\
\text { MOD }\end{array}$ \\
\hline $\begin{array}{l}\text { Kittinger } \\
(2013)\end{array}$ & $\begin{array}{l}\text { North } \\
\text { America }\end{array}$ & USA & & S, E, F, PU & $\mathrm{x}$ & $\mathrm{x}$ & $\mathrm{x}$ & MET, INT \\
\hline $\begin{array}{l}\text { Lorance et al. } \\
\text { (2011) }\end{array}$ & Europe & - & & $\mathrm{S}, \mathrm{PO}, \mathrm{E}, \mathrm{F}$ & & & $\mathrm{x}$ & $\begin{array}{l}\text { WOR, } \\
\text { DIS, INT, } \\
\text { QUE, } \\
\text { MAP }\end{array}$ \\
\hline $\begin{array}{l}\text { Mabon and } \\
\text { Kawabe (2015) }\end{array}$ & Asia & Japan & & $\begin{array}{l}\text { S, PO, F, } \\
\text { RI }\end{array}$ & & & $\mathrm{x}$ & $\begin{array}{l}\text { MET, } \\
\text { DIS, INT }\end{array}$ \\
\hline $\begin{array}{l}\text { Mahon et al. } \\
(2003)\end{array}$ & $\begin{array}{l}\text { North } \\
\text { America }\end{array}$ & Barbados & & PO, F, PU & $\mathrm{x}$ & & $\mathrm{x}$ & $\begin{array}{l}\text { WOR, } \\
\text { CON }\end{array}$ \\
\hline $\begin{array}{l}\text { Mapstone et al. } \\
(2008)\end{array}$ & Australia & Australia & & $\begin{array}{l}\text { PO, E, F, } \\
\text { RI }\end{array}$ & & & $\mathrm{x}$ & $\begin{array}{l}\text { MET, } \\
\text { WOR, } \\
\text { MOD }\end{array}$ \\
\hline $\begin{array}{l}\text { Miller et al. } \\
(2010)\end{array}$ & $\begin{array}{l}\text { North } \\
\text { America }\end{array}$ & USA & & $\begin{array}{l}\text { S, PO, E, } \\
\text { F, RF, RI }\end{array}$ & $\mathrm{x}$ & & $\mathrm{x}$ & $\begin{array}{l}\text { MET, } \\
\text { WOR, } \\
\text { DIS, } \\
\text { MOD, } \\
\text { COO }\end{array}$ \\
\hline $\begin{array}{l}\text { Mitchell and } \\
\text { Baba (2006) }\end{array}$ & Australia & Australia & & $\mathrm{F}, \mathrm{RF}$ & & & $\mathrm{x}$ & $\begin{array}{l}\text { QUE, } \\
\text { SUR }\end{array}$ \\
\hline $\begin{array}{l}\text { Murphy et al. } \\
\text { (2015) }\end{array}$ & $\begin{array}{l}\text { North } \\
\text { America }\end{array}$ & USA & & F, RF, RI & $\mathrm{x}$ & & $\mathrm{x}$ & SUR \\
\hline $\begin{array}{l}\text { Pristupa et al. } \\
\text { (2016) }\end{array}$ & Europe & Russia & & $\begin{array}{l}\text { S, PO, F, } \\
\text { RI, PU }\end{array}$ & $\mathrm{x}$ & $\mathrm{x}$ & $\mathrm{x}$ & INT \\
\hline $\begin{array}{l}\text { Punt et al. } \\
\text { (2012) }\end{array}$ & Australia & Australia & & $\begin{array}{l}\text { S, PO, F, } \\
\text { RI }\end{array}$ & & & & \\
\hline
\end{tabular}


Table 2.A2 (continued)

\begin{tabular}{|c|c|c|c|c|c|c|c|c|}
\hline Author & Continent & Country & $\begin{array}{l}\text { Definition of } \\
\text { stakeholder? }\end{array}$ & $\begin{array}{l}\text { Type of } \\
\text { stakeholder }\end{array}$ & $\begin{array}{l}\text { Stakeholder } \\
\text { analysis } \\
\text { approach? }\end{array}$ & $\begin{array}{l}\text { Definition of } \\
\text { participation? }\end{array}$ & $\begin{array}{l}\text { Description of } \\
\text { participatory } \\
\text { method? }\end{array}$ & $\begin{array}{l}\text { Which } \\
\text { methods } \\
\text { has been } \\
\text { used? }\end{array}$ \\
\hline $\begin{array}{l}\text { Rivera et al. } \\
(2017)\end{array}$ & Europe & Spain & & $\mathrm{PO}, \mathrm{F}, \mathrm{PU}$ & & & $\mathrm{x}$ & $\begin{array}{l}\text { DIS, INT, } \\
\text { QUE }\end{array}$ \\
\hline $\begin{array}{l}\text { Sampedro et al. } \\
\text { (2017) }\end{array}$ & Europe & Spain, Portugal & & $\mathrm{S}, \mathrm{E}, \mathrm{F}, \mathrm{O}$ & $\mathrm{x}$ & $\mathrm{x}$ & $\mathrm{x}$ & $\begin{array}{l}\text { MET, } \\
\text { WOR, } \\
\text { INT, } \\
\text { SUR, } \\
\text { MOD }\end{array}$ \\
\hline $\begin{array}{l}\text { Smith et al. } \\
\text { (2001) }\end{array}$ & Australia & Australia & & $\begin{array}{l}\text { S, PO, E, } \\
\text { F, RI }\end{array}$ & & & $\mathrm{x}$ & $\begin{array}{l}\text { MET, } \\
\text { WOR }\end{array}$ \\
\hline $\begin{array}{l}\text { Stöhr et al. } \\
\text { (2014) }\end{array}$ & Europe & Sweden, Poland & & $\mathrm{S}, \mathrm{PO}, \mathrm{E}, \mathrm{F}$ & & & $\mathrm{x}$ & MET, INT \\
\hline $\begin{array}{l}\text { Stratoudakis } \\
\text { et al. (2015) }\end{array}$ & Europe & Portugal & & $\mathrm{S}, \mathrm{PO}, \mathrm{F}, \mathrm{O}$ & $\mathrm{x}$ & & $\mathrm{x}$ & $\begin{array}{l}\text { MET, } \\
\text { WOR }\end{array}$ \\
\hline $\begin{array}{l}\text { Thiault et al. } \\
\text { (2017) }\end{array}$ & Asia & French Polynesia & & F & $\mathrm{x}$ & & $\mathrm{x}$ & SUR \\
\hline $\begin{array}{l}\text { Tiller et al. } \\
(2015)\end{array}$ & Europe & Norway & $\mathrm{x}$ & $\mathrm{F}$ & & $\mathrm{x}$ & $\mathrm{x}$ & $\begin{array}{l}\text { WOR, } \\
\text { INT, } \\
\text { QUE, } \\
\text { MOD }\end{array}$ \\
\hline $\begin{array}{l}\text { Trimble and } \\
\text { Berkes (2013) }\end{array}$ & $\begin{array}{l}\text { South } \\
\text { America }\end{array}$ & Uruguay & & $\mathrm{S}, \mathrm{PO}, \mathrm{E}, \mathrm{F}$ & $\mathrm{x}$ & & $\mathrm{x}$ & $\begin{array}{l}\text { MET, } \\
\text { WOR, } \\
\text { CON, } \\
\text { INT }\end{array}$ \\
\hline $\begin{array}{l}\text { Trimble and } \\
\text { Lazaro (2014) }\end{array}$ & $\begin{array}{l}\text { South } \\
\text { America }\end{array}$ & Uruguay & & S, PO, E, F & $\mathrm{x}$ & $\mathrm{x}$ & $\mathrm{x}$ & $\begin{array}{l}\text { MET, } \\
\text { WOR, } \\
\text { CON, } \\
\text { INT, QUE }\end{array}$ \\
\hline $\begin{array}{l}\text { Watters et al. } \\
\text { (2013) }\end{array}$ & NA & $\begin{array}{l}\text { Scotia Sea, Drake } \\
\text { Passage }\end{array}$ & & $\mathrm{F}, \mathrm{O}$ & & & $\mathrm{x}$ & MOD \\
\hline $\begin{array}{l}\text { Williams et al. } \\
\text { (2011) }\end{array}$ & Australia & Australia & & $\mathrm{PO}, \mathrm{F}$ & & & $\mathrm{x}$ & $\begin{array}{l}\text { WOR, } \\
\text { DIS, } \\
\text { MOD }\end{array}$ \\
\hline $\begin{array}{l}\text { Yáñez et al. } \\
\text { (2014) }\end{array}$ & $\begin{array}{l}\text { South } \\
\text { America }\end{array}$ & Chile & & $\mathrm{S}, \mathrm{PO}, \mathrm{F}$ & & & $\mathrm{x}$ & $\begin{array}{l}\text { WOR, } \\
\text { SUR }\end{array}$ \\
\hline $\begin{array}{l}\text { Zengin et al. } \\
\text { (2018) }\end{array}$ & Europe & $\begin{array}{l}\text { Riparian } \\
\text { Countries }\end{array}$ & & $\begin{array}{l}\text { PO, F, RI, } \\
\text { PU }\end{array}$ & & & $\mathrm{x}$ & $\begin{array}{l}\text { DIS, PRE, } \\
\text { COO }\end{array}$ \\
\hline
\end{tabular}

\section{References}

Aanesen M, Armstrong CW, Bloomfield HJ et al (2014) What does stakeholder involvement mean for fisheries management. Ecol Soc 19(4):35

Abdi H, Valentin D (2007) Multiple correspondence analysis. In: Salkind NJ (ed) Encyclopedia of measurement and statistics. Sage, Thousand Oaks

Almeida A, Ameryk A, Campos B et al (2017) Study on Mitigation Measures to Minimise Seabird Bycatch in Gillnet fisheries. European Commission. available at: https://publications.europa.eu/en/publication-detail/-/publication/ f426200b-1138-11e8-9253-01aa75ed71a1/language-en

Angelstam P, Andersson K, Annerstedt M et al (2013) Solving problems in social-ecological systems: definition, practice and barriers of transdisciplinary research. Ambio 42(2):254-265. https://doi. org/10.1007/s13280-012-0372-4

Appeldoorn RS (2008) Transforming reef fisheries management: application of an ecosystem-based approach in the USA Caribbean. Environ Conserv 35(3):232-241

Arnold JS, Fernandez-Gimenez M (2007) Building social capital through participatory research: an analysis of collaboration on Tohono O'odham tribal rangelands in Arizona. Soc Nat Resour 20:481-495

Arnstein SR (1969) A ladder of citizen participation. J Am Plan Assoc 35(4):216-224

Berkes F (2003) Alternatives to conventional management: lessons from small-scale fisheries. Environments 31:5-19

Biggs S (1989) Resource-poor farmer participation in research: a synthesis of experiences from nine national agricultural research systems. OFCOR Comparative Study Paper 3, International Service for National Agricultural Research, The Hague 
Bitunjac I, Jajac N, Katavic I (2016) Decision support to sustainable management of bottom trawl fleet. Sustainability 8:204

Bojorquez-Tapia LA, Pedroza D, Ponce-Diaz G et al (2016) A continual engagement framework to tackle wicked problems: curtailing loggerhead sea turtle fishing bycatch in Gulf of Ulloa, Mexico. Sustain Sci 12:535-548

Brandt P, Ernst A, Gralla F et al (2013) A review of transdisciplinary research in sustainability science. Ecol Econ 92:1-15

Brzezinski DT, Wilson J, Chen Y (2010) Voluntary participation in regional fisheries management council meetings. Ecol Soc 15(3):2

Burdon D, Boyes SJ, Elliott $M$ et al (2018) Integrating natural and social sciences to manage sustainably vectors of change in the marine environment: Dogger Bank transnational case study. Estuar Coast Shelf Sci 201:234-247

Butler JRA, Young JC, McMyn IAG et al (2015) Evaluating adaptive co-management as conservation conflict resolution: learning from seals and salmon. J Environ Manag 160:212-225

Carr LM, Heyman WD (2012) "It's about seeing what's actually out there": quantifying fishers' ecological knowledge and biases in a small-scale commercial fishery as a path toward co-management. Ocean Coast Manage 69:118-132

Carvalho N, Edwards-Jones G, Isidro E (2011) Defining scale in fisheries: small versus large-scale fishing operations in the Azores. Fish Res 109:360-369

Catedrilla LC, Espectato LN, Serofia GD et al (2012) Fisheries law enforcement and compliance in District 1, Iloilo Province, Philippines. Ocean Coast Manage 60:31-37

Clarke S, Leung Wai-yin A, Mak YM et al (2002) Consultation with local fishers on the Hong Kong artificial reefs initiative. ICES J Mar Sci 59:171-177

Cleland D (2017) A playful shift: Field-based experimental games offer insight into capacity reduction in small-scale fisheries. Ocean Coast Manage 144:129-137

Coelho Dias da Silva AC, Comin de Castilhos J, Pinheiro dos Santos EA et al (2010) Efforts to reduce sea turtle bycatch in the shrimp fishery in Northeastern Brazil through a co-management process. Ocean Coast Manage 53(9):570-576

Commission of the European Communities (EC) (2013) Regulation (EU) No 1380/2013 of the European Parliament and of the Council. Brussels

Cox SP, Kronlund AR (2008) Practical stakeholder-driven harvest policies for groundfish fisheries in British Columbia, Canada. Fish Res 94:224-237

Davis A, Hanson JM, Watts H, MacPherson H (2004) Local ecological knowledge and marine fisheries research. The case of white hake (Urophycis tenuis) predation on juvenile American lobster (Homarus americanus). Can J Fish Aquat Sci 61(7):1191-1201

Delaney AE, McLay HA, van Densen WLT (2007) Influences of discourse on decision-making in EU fisheries management: the case of North Sea cod (Gadus morhua). ICES J Mar Sci 64:804-810

Dowling NA, Smith DC, Knuckey I et al (2008) Developing harvest strategies for low-value and data-poor fisheries: case studies from three Australian fisheries. Fish Res 94(3):380-390

Durham E, Baker H, Smith M et al (2014) The BiodivERsA stakeholder engagement handbook. BiodivERsA, Paris

Eriksson H, Adhuric DS, Adriantod L et al (2016) An ecosystem approach to small-scale fisheries through participatory diagnosis in four tropical countries. Global Environ Chang 36:56-66

Eveson JP, Hobday JA, Hartog JR et al (2015) Seasonal forecasting of tuna habitat in the Great Australian Bight. Fish Res 170:39-49

Field JG, Attwood CG, Jarre A et al (2013) Cooperation between scientists, NGOs and industry in support of sustainable fisheries: the
South African hake Merluccius spp. trawl fishery experience. J Fish Biol 83:1019-1034

Fletcher W (2005) The application of qualitative risk assessment methodology to prioritize issues for fisheries management. ICES J Mar Sci 62:1576-1587

Freeman RE (2010) Strategic management: a stakeholder approach. Cambridge University Press, New York

Garza-Gil MD, Amigo-Dobano L, Surís-Regueiro JC et al (2015) Perceptions on incentives for compliance with regulation. The case of Spanish fishermen in the Atlantic. Fish Res 170:30-38

Goetz S, Read FL, Ferreira M et al (2015) Cetacean occurrence, habitat preferences and potential for cetacean-fishery interactions in Iberian Atlantic waters: results from cooperative research involving local stakeholders. Aquat Conserv Mar Freshw Ecosyst $25: 138-154$

Granados-Dieseldorff P, Heyman WD, Azuetad J (2013) History and co-management of the artisanal mutton snapper (Lutjanus analis) spawning aggregation fishery at Gladden Spit, Belize, 1950-2011. Fish Res 147:213-221

Gray S, Chan A, Clark D et al (2012) Modeling the integration of stakeholder knowledge in social-ecological decision-making: benefits and limitations to knowledge diversity. Ecol Model 229:88-96

Green AO, Hunton-Clarke L (2003) A typology of stakeholder participation for company environmental decision-making. Bus Strateg Environ 12:292-299

Greenacre MJ (1984) Theory and applications of correspondence analysis. Academic Press, London

Haapasaari P, Mäntyniemi S, Kuikka S (2013) Involving stakeholders in building integrated fisheries models using Bayesian methods. Environ Manag 51(6):1247-1261

Häberli R, Bill A, Grossenbacher-Mansuy W et al (2001) Synthesis. In: Thompson Klein J, Grossenbacher-Mansuy W, Häberli R et al (eds) Transdisciplinarity: joint problem solving among science, technology, and society. An effective way for managing complexity. Birkhäuser, Basel, pp 6-22

Hara MM, Rogerson J, de Goede J et al (2014) Fragmented participation in management of the fishery for small pelagic fish in South Africa - inclusion of small-rights holders is a complex matter. African J Mar Sci 36(2):185-196

Hartley T, Robertson R (2006) Stakeholder engagement, cooperative fisheries research, and democratic science: the case of the Northeast Consortium. Hum Ecol Rev 13:161-171

Hickey S, Kothari U (2009) Participation. International Encyclopedia of Human Geography, pp. 82-89

Higgs NT (1991) Practical and innovative uses of correspondence analysis. Statistician 40:183-194

Johannes RE, Neis B (2007) The value of anecdote. In: Haggan N, Neis B, Baird IG (eds) Fishers knowledge in fisheries science and management, Coastal Management Sourcebooks, 4. UNESCO, Paris, pp 41-58

Johnson TR, van Densen WLT (2007) Benefits and organization of cooperative research for fisheries management. ICES J Mar Sci 64:834-840

Kaiser M, Forsberg EM (2001) Assessing fisheries - using an ethical matrix in a participatory process. J Agric Environ Ethics 14:191-200

Kerr S, Johnson K, Side J et al (2006) Resolving conflicts in selecting a programme of fisheries science investigation. Fish Res 79:313-324

Kindon S (2008) Participatory action research. In: Hay I (ed) Qualitative research methods in human geography. Oxford University Press, Melbourne, pp 207-220 
Kinds A, Sys K, Schotte L et al (2016) VALDUVIS: an innovative approach to assess the sustainability of fishing activities. Fish Res 182:158-171

Kittinger JN (2013) Participatory fishing community assessments to support coral reef fisheries co-management. Pacific Sci 67(3): $1-43$

Long RD, Charles A, Stephenson RL (2015) Key principles of marine ecosystem-based management. Mar Policy 57:53-60

Lorance P, Agnarsson S, Damalas D et al (2011) Using qualitative and quantitative stakeholder knowledge: examples from European deepwater fisheries. ICES J Mar Sci 68(8):1815-1824

Luyet V, Schlaepfer R, Parlange MB et al (2012) A framework to implement Stakeholder participation in environmental projects. J Environ Manag 111:213-219

Mabon L, Kawabe M (2015) Fisheries in Iwaki after the Fukushima Dai'ichi nuclear accident: lessons for coastal management under conditions of high uncertainty? Coast Manage 43(5):498-518

Mackinson S, Wilson DC, Galiay P et al (2011) Engaging stakeholders in fisheries and marine research. Mar Policy 35(1):18-24

Mahon R, Almerigi S, McConney P et al (2003) Participatory methodology used for sea urchin co-management in Barbados. Ocean Coast Manage 46:1-25

Mapstone BD, Little LR, Punt AE et al (2008) Management strategy evaluation for line fishing in the Great Barrier Reef: balancing conservation and multi-sector fishery objectives. Fish Res 94:315-329

Mayring P (1988) Die qualitative Wende. Arbeiten zur qualitativen Forschung. Augsburger Berichte zur Entwicklungspsychologie und Pädagogischen Psychologie, vol 32

Miller TJ, Blair JA, Ihde TF et al (2010) FishSmart: an innovative role for science in stakeholder-centered approaches to fisheries management. Fisheries 35(9):424-433

Mitchell R, Baba O (2006) Multi-sector resource allocation and integrated management of abalone stocks in Western Australia: review and discussion of management strategies. Fish Sci $72: 278-288$

Murphy RD, Scyphers SB, Grabowski JH (2015) Assessing fishers' support of striped bass management strategies. PLoS One 10:e0136412

Neis B, Schneider DC, Felt L et al (1999) Fisheries assessment: what can be learned from interviewing resource users. Can J Fish Aquat Sci 56:1949-1963

Newig J, Fritsch O (2009) The case survey method and applications in political Science: Paper Presented at the APSA 2009 Meeting, 3-6 September 2009, Toronto

NOAA (2015) Introduction to stakeholder participation. Office for coastal management. Available at: https://coast.noaa.gov/data/digitalcoast/pdf/stakeholder-participation.pdf. Accessed 18 July 2018

Okali C, Sumberg J, Farrington J (1994) Farmer participatory research. Intermediate Technology Publications, London

Olson M (1965) The logic of collective action. Harvard University Press, Cambridge

Pomeroy RS (2012) Managing overcapacity in small-scale fisheries in Southeast Asia. Mar Policy 36:520-527

Pretty J, Shah P (1994) Soil and water conservation in the twentieth century: a history of coercion and control. University of Reading Rural History Centre, 1

Pristupa AO, Lamers M, Amelung B (2016) Private informational governance in post-soviet waters: implications of the marine stewardship council certification in the Russian Barents Sea region. Fish Res 182:128-135
Punt AE, McGarvey R, Linnane A et al (2012) Evaluating empirical decision rules for southern rock lobster fisheries: a South Australian example. Fish Res 115-116:60-71

Reed MS (2008) Stakeholder participation for environmental management: a literature review. Biol Conserv 141:2417-2431

Repko AF, Newell WH, Szostak R (2011) Case studies in interdisciplinary research. Sage, Thousand Oaks

Rivera A, Gelcich S, García-Flórez L et al (2017) Trends, drivers, and lessons from a long-term data series of the Asturian (northern Spain) gooseneck barnacle territorial use rights system. Bull Mar Sci 93(1):35-51

Rowe G, Frewer L (2000) Public participation methods: a framework for evaluation in science. Sci Technol Hum Values 25:3-29

Sampedro P, Prellezo R, Garcia D et al (2017) To shape or to be shaped: engaging stakeholders in fishery management advice. ICES J Mar Sci 74(2):487-498

Smith DC, Smith ADM, Punt AE (2001) Approach and process for stock assessment in the South East fishery, Australia: a perspective. Mar Freshw Res 52:671-681

Soma K, Vatn A (2014) Representing the common goods - stakeholders vs. citizens. Land Use Policy 41:325-333

Stöhr C, Lundholm C, Crona B et al (2014) Stakeholder participation and sustainable fisheries: an integrative framework for assessing adaptive comanagement processes. Ecol Soc 19:14

Stratoudakis Y, Azevedo M, Farias I et al (2015) Benchmarking for data-limited fishery systems to support collaborative focus on solutions. Fish Res 171:122-129

Thiault L, Collin A, Chlous F et al (2017) Combining participatory and socioeconomic approaches to map fishing effort in small-scale fisheries. PLoS One 12(5):1-18

Thomas J (1993) Public involvement and governmental effectiveness: a decision-making model for public managers. Adm Soc $24: 444-469$

Thomas G (2011) A typology for the case study in social science following a review of definition, discourse, and structure. Qual Inq 17(6):511-521. https://doi.org/10.1177/1077800411409884

Tiller RG, Mork J, Liu Y et al (2015) To adapt or not adapt: assessing the adaptive capacity of artisanal fishers in the Trondheimsfjord (Norway) to jellyfish (Periphylla periphylla) bloom and purse seiners. Mar Coast Fish 7:260-273

Trimble M, Berkes F (2013) Participatory research towards comanagement: lessons from artisanal fisheries in coastal Uruguay. J Environ Manag 128:768-778

Trimble M, Lazaro M (2014) Evaluation criteria for participatory research: insights from coastal Uruguay. Environ Manag 54:122-137

Voinov A, Bousquet F (2010) Modelling with stakeholders. Environ Model Softw 25:1268-1281

Watters GM, Hill SL, Hinke JT et al (2013) Decision-making for ecosystem-based management: evaluating options for a krill fishery with an ecosystem dynamics model. Ecol Appl 23(4):710-725

Whyte WF, Greenwood DJ, Lazes P (1989) Participatory action research: through practice to science in social research. Am Behav Sci 32:513-551

Williams AJ, Little LR, Begg GA (2011) Balancing indigenous and non-indigenous commercial objectives in a coral reef finfish fishery. ICES J Mar Sci 68(5):834-847

Wilson DG, Nielsen JR, Degnbol P (2003) The fisheries co-management experience: accomplishments, challenges and prospects. Kluwer Academic, Dordrecht 
Yáñez E, Silva C, Barbieri MA et al (2014) Socio-ecological analysis of the artisanal fishing system on Easter Island. Lat Am J of Aquat Res 42(4):803-813

Yates KL, Schoeman DS (2015) Incorporating the spatial access priorities of fishers into strategic conservation planning and marine protected area design: reducing cost and increasing transparency. ICES J Mar Sci 72(2):587-594
Zengin M, Mihneva V, Duzgunes E (2018) Analysing the need of communication to improve Black Sea fisheries management policies in the Riparian Countries. Turk J Fish Aquat Sci 18:199-209

ETH Zürich (2018) Web of science core collection. Available at: www. library.ethz.ch/Ressourcen/Datenbanken/Web-of-Science-CoreCollection. Accessed 25 July 2018

Open Access This chapter is licensed under the terms of the Creative Commons Attribution 4.0 International License (http://creativecommons. $\mathrm{org} /$ licenses/by/4.0/), which permits use, sharing, adaptation, distribution and reproduction in any medium or format, as long as you give appropriate credit to the original author(s) and the source, provide a link to the Creative Commons license and indicate if changes were made.

The images or other third party material in this chapter are included in the chapter's Creative Commons license, unless indicated otherwise in a credit line to the material. If material is not included in the chapter's Creative Commons license and your intended use is not permitted by statutory regulation or exceeds the permitted use, you will need to obtain permission directly from the copyright holder. 